\title{
Wkład Polaków w rozwój misji mariannhillskiej na przełomie XIX i XX wieku w południowej Afryce
}

\section{Contribution of Poles to the development of Marianhill mission in southern Africa} at the turn of the $19^{\text {th }}$ and $20^{\text {th }}$ centuries

Misja mariannhillska w południowej Afryce, stanowi bardzo dobry przykład nie tylko bezpośredniego zaangażowana w dzieło misyjne Polaków w Afryce, ale również staje się wspaniałym przykładem animacji misyjnej w Polsce przełomu XIX i XX wieku oraz niezwykłym wzorem wspierania tego dzieła misyjnego przez Polaków w ojczyźnie. O ile wkład Polaków w takie dzieła, jak wybudowanie leprozorium w Marana na Madagaskarze (przez bł. o. Jana Beyzyma) czy praca kilkunastu jezuitów w tym okresie w misji zambeskiej są powszechnie znane, o tyle działalność misyjna około 80 misjonarzy i misjonarek misji mariannhillskiej pozostaje praktycznie nieznana. Zasadniczymi źródłami artykułu są archiwa misji mariannhillskiej w Rzymie oraz pismo „Niezapominajki” - „Wiadomości Misyjne”, a także „Polski Kalendarz Misyjny”, które w latach 18891940 ukazywały się w Polsce.

\section{PRZYBYCIE TRAPISTÓW ${ }^{1}$}

W 1874 roku erygowano wikariat apostolski Przylądka Wschodniego ze stolicą w Port Elizabeth, którego biskupem został James David Ricards². Ze wzglę-

${ }^{1}$ Zakon Cystersów Ściślejszej Obserwancji, Ordo Cisterciensium Strictionis Observantiae, Ordo Cisterciensium Reformatorum (OSCO, OCR), zakon mniszy, założony we francuskim klasztorze cysterskim La Trappe (Normandia) przez opata A. J. Le Bouthilliera de Rancé (1664). Początkowo nurt obserwancki w obrębie cystersów, dążący do rygorystycznego przestrzegania reguły. Zatwierdzony w 1705 r. przez papieża Klemensa XI, od 1894 odrębny zakon. Reguła uważana za najsurowszą w monastycyzmie zachodnim, zakłada pełną izolację od świata, milczenie, posty (zakaz spożywania mięsa i nabiału), oddanie się modlitwie, kontemplacji i pracy fizycznej. Pierwsze klasztory powstawały gł. we Francji i Włoszech, obecnie są również w innych krajach Europy i w obu Amerykach. Por. Wielka Encyklopedia PWN, t. 27, Warszawa 2005, s. 573-574.

${ }^{2}$ Zanim został Wikariuszem Apostolskim znany był jako duszpasterz, profesor, pisarz i wy- 
du na brak misjonarzy w swojej diecezji w ich poszukiwaniu wyruszył do Europy. W 1879 roku dotarł do Septfons we Francji, gdzie właśnie odbywała się kapituła generalna trapistów ${ }^{3}$. Biskup Ricards zwrócił się do nich z prośbą o objęcie jednej z placówek misyjnych w swojej diecezji. Przedstawił zebranym ojcom chęć posiadania klasztoru trapistów w swoim wikariacie, w celu nawracania czarnych mieszkańców oraz podniesienia poziomu kultury rolnej. Bp Ricards poczynił szereg zachęcających obietnic, zobowiązując się do uposażenia nowego klasztoru w farmę o powierzchni 1620 hektarów, pokrycia kosztów budowy budynków przyklasztornych, zakup sprzętów potrzebnych do uprawy ziemi i nasion oraz pokrycia kosztów utrzymania wspólnoty do czasu samowystarczalności ${ }^{4}$. Po wahaniach zebranych ojców, pomimo, że misje zamorskie nie należały do zakresu działalności trapistów, zgłosił się zdecydowany na wszystko o. Franciszek Pfanner $^{5}$ wypowiadając swe słynne zdanie: Jeśli nikt nie chce iść, ide ja $a^{6}$. Dla tego misyjnego zadania aprobaty udzielił nawet sam papież Leon XII ${ }^{7}$.

21 czerwca 1880 roku grupa trzydziestu jeden trapistów wyruszyła z klasztoru Mariastern w Bośni w podróż do południowej Afryki. Bp Ricards na przejazd całej grupy wynajął mały statek parowy. Po ponad czterech tygodniach żeglugi wszyscy podróżnicy z różnego rodzaju sprzętami potrzebnymi im na nowej ziemi wylądowali 28 lipca 1880 roku w Port Elizabeth. Dalszą część drogi pokonali pociagiem a następnie wozami dotarli na miejsce swego przeznaczenia. Oczekiwał na nich nowy klasztor - prymitywny budynek z falistej blachy. Klasz-

dawca pierwszej gazety katolickiej pt. „Kolonista” w południowej Afryce [ukazywała się od 20 grudnia 1850 r.] Ceniono go nie tylko jako pioniera krzewienia wiary, lecz także kultury w kraju. Por. Na śladach opata Franciszka, „Wiadomości Misyjne” (1938), s. 100.

${ }^{3}$ Por. E. Bogucka, Chrystus przychodzi do wydziedziczonych, „Misyjne Drogi” (1984) nr 3, s. 8; por. także, 50-rocznica założenia klasztoru Mariannhill, „Polski Kalendarz Misyjny” (1932), s. 21.

${ }^{4}$ Por. K. Zacharuk, Idee misyjne Zgromadzenia Misjonarzy z Mariannhill, [mps] Kraków 2001, s. 18 , przypis 71 .

${ }^{5}$ Franciszek (Wendelin - imię chrzcielne) Pfanner urodził się 21 września 1825 roku w Langenhub koło Bregenz w Austrii, w rolniczej rodzinie Antoniego i Anny Pfannerów. 28 lipca 1850 roku z rąk biskupa Bernharda Galura otrzymał święcenia kapłańskie. Po czterotygodniowym urlopie został zarządcą parafii w Haselstauden-Dornbirn, a dwa lata później proboszczem. W 1859 roku biskup Galur wysłał Pfannera, jako spowiednika dla wspólnoty Sióstr Miłosierdzia do Agram (dzisiejsze miasto Zagrzeb w Chorwacji). 17 września 1863 roku Wendelin wstapił do Zakonu Trapistów w Eifel. W dniu obłóczyn 9 października otrzymał biały strój zakonny nowicjusza i nowe imię Franciszek. Przełożeni klasztoru w Eifel bardzo szybko rozpoznali zdolności ojca Franciszka i okazali mu swoje zaufanie. Już kilka tygodni po jego pierwszych ślubach został mianowany podprzeorem klasztoru. Wrodzony zapał do pracy pociagnął go do wybudowania od podstaw klasztoru Mariastern w Banja Luce, w ówczesnej i wrogiej chrześcijaństwu Bośni. Od 1880 r. aż do śmierci 24 maja 1909 r. jako misjonarz pracował w południowej Afryce. Por. Misjonarze z Mariannhill, [hasło w:] Leksykon zakonów w Polsce, B. Łoziński (red.), Warszawa 2002, s. 88.

${ }^{6}$ Por. tamże, s. 88.

${ }^{7}$ Por. K. Zacharuk, dz. cyt., s. 19, przypis 72. 
tor został nazwany na pamiątkę starego opactwa cysterskiego w Irlandii - Dunbrody. Pfanner do tej nazwy dodał imię Matki Bożej „Maria-Dunbrody”. „Od samego początku mnisi zabrali się do pracy przy nowym klasztorze, każdy w swej specjalności. W krótkim czasie powstały nowe zabudowania klasztorne jak: kościół, sypialnia, jadalnia. Na przygotowanych polach mnisi rozpoczęli uprawę pszenicy i ziemniaków. Pomimo intensywnej pracy plony z pól były prawie żadne. Uboga w wodę okolica, duża liczba dzikich zwierząt i szkodników skutecznie niszczyły wszelkie uprawy rolne" ". Coraz częściej stawało się jasne, że to miejsce jest niewłaściwe dla misji trapistów ${ }^{10}$. Biskup Ricards oznajmił, że nie ma już więcej środków finansowych na utrzymanie, które obiecał podczas kapituły w Septfons we Francji11.

„Dnia 12 września 1881 roku przeor Pfanner udał się w podróż do Europy na Kapitułę Generalną Zakonu Trapistów w Paryżu. Uzyskał na niej potrzebne poparcie dla swoich przedsięwzięć, aby pod pewnymi warunkami dalej działać w Dunbrody. Po kapitule udał się do klasztoru Mariastern w Bośni, aby tam przedstawić postanowienia kapituły i opowiedzieć o życiu w klasztorze MariaDunbrody. Pozyskał też kolejnych dziesięciu braci, którzy mieli wyjechać do klasztoru w południowej Afryce. Następnie rozpoczął swoją podróż po Europie"12. Oprócz Niemiec, dużej części Austrii i Szwajcarii, odwiedził także polskie prowincje: Górny Śląsk, Pomorze i Poznańskie, zbierając datki na nowy klasztor misyjny i zachęcając do współpracy misyjnej. Przeor Franciszek poprzez swoje odczyty wywierał ogromne wrażenie na młodzieży. Pozyskał w ten sposób czterech polskich młodzieńców, gotowych do pracy w nowopowstającej misji ${ }^{13}$.

\footnotetext{
${ }^{8}$ Por. tamże, przypis 73.

${ }^{9}$ Tamże, przypis 74.

${ }^{10}$ Por. Misjonarze z Mariannhill, dz. cyt., s. 88; por. także, Dwa listy polskie z poludniowej Afryki, ,Misje Katolickie” (1884), s. 367.

${ }^{11}$ Por. T. Telega, Działalność misyjna Zakonu Trapistów w Afryce Poludniowej w latach 1880-1909, [mps] Kraków 2005, s. 42, przypis 55.

${ }^{12}$ Tamże, s. 43, przypis 57.

${ }^{13}$ Byli to: o. Ansgar Szczygieł z Pomorza, o. Jacek Salomon, o. Anzelm Skotnik i br. Rustyk Hajduga. Por. K. Kowalewski, „Polski” Mariannhill po latach pięćdziesięciu, „Misje Katolickie” (1934), s. 356-357; por. także, J. Kępiński, Polscy misjonarze w Afryce wczoraj, [w:] Maria Teresa Ledóchowska i misje, B. Bejze, J. Gucwa, A. Koszorz (red.), Warszawa 1977, s. 222; por. także, A. Żukowski, Polacy w kraju Springboka do r. 1910, „Przegląd Polonijny” (1990) z. 4, s. 119; por. tenże, Wkład Polaków w rozwój Kościoła katolickiego w Afryce Poludniowej, „Misyjne Drogi” (1994) nr 4, s. 27; W kraju złota i diamentów. Polacy w Afryce Poludniowej XVI-XX w., Warszawa 1994, s. 94; Udziat Polaków w założeniu Misji Mariannhillskiej w Natalu, w Afryce Poludniowej, [w:] Duchowieństwo Polskie w świecie. Materiały VII Międzynarodowego Sympozjum Biografistyki Polonijnej, Rzym, 17-18 października 2002, Agata i Zbigniew Judyccy (red.), Toruń 2002, s. 408; por. także, A. Halemba, Polscy misjonarze w Afryce wczoraj i dziś, „Światło Narodów” (2002) nr 3, s. 38 .
} 
Jednak niesprzyjające warunki klimatyczne, wysoko wyidealizowane idee bpa Ricardsa, które były mało realistyczne oraz doświadczenie i realne spojrzenie przeora Franciszka Pfannera doprowadziły do upadku wielkiego planu osiedlenia się trapistów w Maria-Dunbrody ${ }^{14}$.

Przeor Franciszek Pfanner rozpoczął poszukiwanie dogodniejszego miejsca na klasztor. Udał się do Maritzburga w Natalu do bpa Karola Jolivet'a Wikariusza Apostolskiego Wikariatu Natal i granicznych ziem. Tam dowiedział się o możliwości kupna farmy oddalonej około $150 \mathrm{~km}$ na zachód od Durbanu ${ }^{15} .20$ grudnia 1882 roku przeor Franciszek sprawdził tę farmę, a następnego dnia dokonał jej zakupu ${ }^{16}$. Trapiści opuścili klasztor Maria-Dunbrody z całym swym dobytkiem i drogą morską przybyli do portu Durban. Tam wynajęli 100 par wołów i 14 wozów do przewiezienia swych rzeczy. Po paru dniach podróży 24 grudnia 1882 roku dotarli na miejsce nowo zakupionej farmy ${ }^{17}$. Przyszłą misję, nazwali Wzgórzem Maryi - Anny (Mary - Anne - Hill), stąd dzisiejsze Mariannhill ${ }^{18}$.

\section{POWSTANIE ZGROMADZENIA MISJONARZY Z MARIANNHILL}

Przybycie trapistów do Natalu i osiedlenie się ich w okolicy Durbanu wywołało wielkie zainteresowanie wśród mieszkańców. Katolicy włoscy znajdowali u nich posługę duszpasterską, a władze angielskie doceniały szybki i wszechstronny rozwój gospodarczy. Przyczynił się on do rozwoju prowincji, jak i edukacji zawodowej ludności kaferskiej ${ }^{19}$. Według ojca Pfannera nawracanie na wia-

${ }^{14}$ Por. K. Zacharuk, dz. cyt., s. 19-20, przypis 76.

${ }^{15}$ J. Kępiński, Polscy misjonarze w Afryce wczoraj, [w:] Maria Teresa Ledóchowska i misje, B. Bejze, J. Gucwa, A. Koszorz (red.), Warszawa 1977, s. 221.

${ }^{16}$ Por. T. Telega, dz. cyt., s. 43, przypis 60.

${ }^{17}$ Jak podaje M. Czermiński, miejscowa gazeta Times całe przenosiny opisała następująco: Bracia Trapiści znad poludniowej rzeki zdecydowali się wreszcie, jak styszę, przenieść się w okolicę stosowniejszq dla prac swoich. Szkoda, że tu nie zostali. Gdyby znaleźli sobie grunt i dostatek wody, jak sobie życzyli, byliby swój folwark tak wzorowo urzadzili, że gospodarze wiejscy klas wszystkich dużo mogliby się nauczyć w rozmaitych gatęziach, rolnictwo łaczyć z hodowla bydta, obok nauki maja wiele doświadczenia w tych rzemiosłach. Sprowadzenie takich ludzi do Kolonii kosztowałoby nasz rzad bardzo wiele, gdyby trzeba było ich opłacić. M. Czermiński, Szkice cywilizacyi [sic!] Afryki poludniowej, Kraków 1890, s. 86.

${ }^{18}$ Por. tamże, s. 87-88; por. także Misjonarze z Mariannhill, dz. cyt., s. 88.

${ }^{19}$ Lud należący do rodziny Bantu zajmującej południowo-wschodnie wybrzeża Afryki. W XVI w. Portugalczycy nazwali ich pogardliwie Kaframi, zapożyczając tę nazwę od Arabów (kafir w jęz. arabskim oznacza niewierny). Termin Kafr przejęli później Burowie w stosunku do Afrykanów, zwłaszcza plemienia Khosa. W 1910 r. władze Unii Południowo-Afrykańskiej wprowadziły w stosunku do nich oficjalny termin „tubylcy” (Natives). Od początku lat osiemdziesiątych obowiązuje termin „Afrykanie” (Africans). Por. A. Żukowski, W kraju złota i diamentów, dz. cyt., s. 22, 30. 
rę chrześcijańską Afrykanów żyjących na terenach wokół klasztoru w Mariannhill było procesem bardzo powolnym i wymagało stworzenia wraz z nimi prawdziwej wspólnoty chrześcijańskiejej.

Milcząc, jak tego wymagała reguła najsurowszego zakonu Kościoła, pragnęli poprzez przykład modlitwy i pracy, prowadzić Afrykanów do Chrystusa. O właściwej pracy misyjnej nie myślał wtedy żaden z nich. Chcieli oni oddziaływać na mieszkańców Afryki poprzez swoją obecność i przykład życia zakonnego. To rozbudziło ciekawość tubylców ${ }^{21}$.

1 września 1885 r. do południowej Afryki przybyło pięć młodych dziewcząt z krajów niemieckich. Jeszcze tego samego dnia przyjechały do klasztoru w Mariannhill. Siostry miały przygotowany osobny dom w odległości jednego kilometra od klasztoru ${ }^{22} .8$ września w święto Narodzenia Matki Bożej otrzymały swój nowy strój: czerwoną spódnice, czarną bluzkę, fartuch i biały czepek. Ojciec Franciszek wyjaśnił im, iż czerwony kolor ich stroju symbolizuje krew Chrystusa. Za jego radą siostry wybrały sobie nazwę „Siostry Misjonarki od Drogocennej Krwi”23. Głównym zadaniem sióstr misjonarek była pomoc trapistom w przygotowaniu dziewcząt i kobiet do chrztu świętego. Uczyły je także robót w polu i ogrodzie oraz prac w gospodarstwie domowym: szycia, sprzątania i gotowania. W późniejszym czasie siostry sporadycznie uczyły niektóre dziewczęta czytać i pisać24.

27 grudnia 1885 roku klasztor trapistów w Mariannhill został podniesiony do rangi opactwa. Założyciel klasztoru, przeor Franciszek Pfanner, został jednogłośnie wybrany przez kapitułę generalną opatem ${ }^{25}$. Lata praktyki pokazały jednak, iż bycie trapistą i misjonarzem w jednej osobie jest nie do pogodzenia. Aby być prawdziwym misjonarzem, trzeba byłoby skreślić co najmniej 3/4 reguły trapistowskiej $^{26}$. „W tym celu opat generalny Augustinus Marre opracował nową regułę dla opactwa Mariannhill, chociaż mnisi z Mariannhill nadal pragnęli pozostać w zakonie. Zwołana z polecenia papieskiej Kongregacji Rozkrzewiania Wiary konferencja misyjna w maju 1908 roku położyła kres wszelkim dyskusjom. W sierpniu wszystkie akta dotyczące Mariannhill otrzymał prymas do spraw zakonów benedyktyńskich, opat Hildebrand Heimpfinne. W swym obszernym sprawozdaniu opowiedział się za odłączeniem Mariannhill od zakonu trapistów, ale bez tworzenia nowego zakonu. Prymas zaproponował utworzenie ka-

${ }^{20}$ Tamże, s. 93.

${ }^{21}$ Por. T. Telega, dz. cyt., s. 44-45, przypis 66.

${ }^{22}$ Por. tamże, przypis 73.

${ }^{23}$ Por. Najnowsze wieści misyjne z Mariannhill. Jubileusz w Mariannhill, „Wiadomości Misyjne" (1935), s. 185.

${ }^{24}$ M. Czermiński, dz. cyt., s. 152.

${ }^{25}$ Por. T. Telega, dz. cyt., s. 47, przypis 76.

${ }^{26}$ Por. tamże, s. 41, przypis 139. 
nonicznego kolegium, gdzie część członków zajmowałaby się misjami, a część modlitwą w chórze oraz wychowaniem nowicjuszy i kleryków. Jako nazwę dla nowego instytutu, kardynał zaproponował Religiosi Missionarii de Mariannhill (RMM)"27.

2 lutego 1909 roku papież Pius X, podczas Mszy Świętej w uroczystość Ofiarowania Pańskiego, ogłosił dekret oddzielający opactwo Mariannhill od zakonu trapistów. Dekret rozpoczyna się od pochwał podjętego dzieła misyjnego: „Synowie jednej rodziny zakonnej, wierni tradycji swoich ojców, trudziliście się, aby światło rozprzestrzeniało się wśród pogan w obszernej okolicy przez słowo i przykład. Zaiste, nie zajęliście ostatniego miejsca, tylko przysporzyliście o wiele więcej chwały, każdy Reformowany Cysters, który z klasztoru Mariastern w Bośni wyruszył pod kierunkiem ojca Franciszka Pfannera. W roku 1881 w południowej Afryce założył on opactwo Mariannhill, które ze swymi stacjami misyjnymi oplotło jak sieć, rozległą prowincję Natal”. Następnie dekret określał ustalenia organizacyjne nowej wspólnoty, a w szczególności dotyczył przeora i rady oraz o przymiotach i czasie trwania ślubów. Kierownictwo nowej wspólnocie powierzono opatowi Gerardowi Wolpertowi ${ }^{28}$.

Definitywne oddzielenie opactwa Mariannhill nastapiło 24 lipca 1914 roku, kiedy to papież Pius X na okres siedmiu lat zaaprobował nowe Konstytucje. W 1922 r. niezależne opactwo zostało wikariatem apostolskim, a w 1951 r. diecezją.

Na przełomie XIX i XX w. do misji marianhillskiej w Natalu licznie przybywali ojcowie i bracia oraz siostry zakonne z Polski ${ }^{29}$. Najwięcej przybyło ich w latach 80-tych XIX wieku. Już w 1889 r. w Mariannhill było około 40 Polaków i Polek ${ }^{30}$. Liczba ta rosła w bardzo szybkim tempie, tak, że w okresie największego rozkwitu grupa polskich misjonarzy i misjonarek stanowiła około 70

\footnotetext{
${ }^{27}$ Tamże, przypis 141.

${ }^{28}$ Por. Wiadomości bieżace z misji. Natal. Reorganizacja misji oo. Trapistów, „Misje Katolickie" (1910), s. 116.

${ }^{29}$ Por. A. Żukowski, Polacy w kraju Springboka do r. 1910, dz. cyt., s. 119; por. tenże, Polonia w Afryce Poludniowej, [w:] Almanach Polonii 1991, Warszawa 1990, s. 183; Polacy w RPA. Polonia południowoafrykańska - przeszłość i teraźniejszość, „Ład” (1993) nr 25, s. 5; Wkład Polaków w rozwój Kościoła katolickiego w Afryce Poludniowej, dz. cyt., s. 27; W kraju złota i diamentów, dz. cyt., s. 93; Polacy w Afryce Poludniowej, „Mówią Wieki” (2004) nr 11, s. 38; por. także, A. Halemba, Polscy misjonarze w Afryce wczoraj i dziś, „Światło Narodów” (2002) nr 3, s. 38; por. także, S. Gołąbek, Wychodźstwo Polskie do Afryki, „Przegląd Orientalistyczny” (1972) nr 1, s. 8; por. tenże, Zwiqzki Polski i Polaków z Afrykq do roku 1945, Warszawa-Łódź 1978, s. 46; por. także, J. S. Bystroń, Afryka środkowa i poludniowa, [w:] Polska i Polacy w cywilizacjach świata. Stownik Encyklopedyczny, W. Pobóg-Malinowski (red.), t. 1, Warszawa 1939, s. 19-20; por. także, J. Krzyszkowski, Przez pola misyjne, Kraków 1925, s. 37.

${ }^{30}$ Por. K. Kapitańczyk, Udział Polski w dziele misyjnym. Szkic historyczny, Poznań 1933, s. 119,121 .
} 
osób. Była to najliczniejsza grupa Polaków pracująca w tym czasie w Afryce. Działali oni w ramach niemieckiego zgromadzenia, niemniej jednak dawali szereg dowodów zainteresowania ojczyzną i okazywania swojej polskości ${ }^{31}$. Pod koniec XIX wieku klasztor w Mariannhill stał się największym na świecie ośrodkiem misyjnym. Liczył wówczas 285 misjonarzy, w większości braci zakonnych.

\section{POLSCY MISJONARZE W MARIANNHILL}

Jednymi z pierwszych w misji marianhillskiej byli polscy zakonnicy pochodzący z Górnego Śląska, Pomorza i Wielkopolski ${ }^{32}$. Ojciec Jacek [Hjacent - K.P.] Salomon urodził się 20 II 1867 r. w Nowej Wsi Książęcej koło Bralina (dzisiaj województwo wielkopolskie). Do Mariannhill przybył 12 lipca 1883 r., mając 16 lat ${ }^{33}$. Był pierwszym misjonarzem, który nauczył się języka zulusów, z tego też powodu służył opatowi Franciszkowi jako tłumacz. Należał do grupy pionierów, którzy udawali się na wyprawy poznawcze szukając miejsc dla nowych stacji misyjnych. Dzięki bardzo dobrej znajomości miejscowych języków pracował na różnych stacjach misyjnych. Jako katecheta pracował wśród tubylców na stacjach misyjnych Reichenau ${ }^{34}$ - miał wtedy 20 lat - i Mariathal ${ }^{35} .12$ marca $1892 \mathrm{r}$. z rąk miejscowego bpa Karola Jolivet'a OMI otrzymał święcenia kapłańskie a następnego dnia - w drugą Niedzielę Wielkiego Postu odprawił pierwszą Mszę Św. ${ }^{36}$. „Z racji dużych osiagnięć i zasług w dziedzinie oświaty miejscowi nazwa-

${ }^{31}$ Por. W. Szołdrski, Dzieje misji katolickich w zarysie, Kraków 1927, s. 166; por. także, J. Kępiński, dz. cyt., s. 222-223; por. także, A. Żukowski, Polacy w kraju Springboka do r. 1910, dz. cyt., s. 120; por. tenże, Polonia w Afryce Poludniowej, dz. cyt., s. 183; Wkład Polaków w rozwój Kościoła katolickiego w Afryce Poludniowej, dz. cyt., s. 28; W kraju złota i diamentów, dz. cyt., s. 98-99; Polacy w Afryce Poludniowej, dz. cyt., s. 38.

${ }^{32}$ Por. J. Knopek, Afryka Południowa, duszpasterstwo, [hasło w:] Encyklopedia Polskiej Emigracji i Polonii, dz. cyt., s. 36; por. także, A. Żukowski, Polacy w kraju Springboka do r. 1910, dz. cyt., s. 119; por. tenże, $W$ kraju złota i diamentów, dz. cyt., s. 94; Wkład Polaków w rozwój Kościoła katolickiego w Afryce Poludniowej, dz. cyt., s. 27.

${ }^{33}$ Archiwum Misji Mariannhillskiej w Rzymie podaje jako czas jego przybycia do południowej Afryki także rok 1886: „Sehr wahrscheinlich hatte ihn Abt Franz selbst bei seiner Europareise 1886 geworben" (Bardzo prawdopodobnie pozyskał go dla trapistów opat Franciszek podczas swojej podróży po Europie w roku 1886). Por. Archiwum Misji Mariannhillskiej w Rzymie, (dalej: AMM - Rzym), biogram: Pater Hyacinth (Peter) Salomon. Rok 1883 wydaje się jednak bardziej prawdopodobny gdyż z dalszej informacji wynika, że przybył on do Mariannhill w wieku 16 lat. W roku 1886 miałby on lat 19 .

${ }^{34}$ Była to pierwsza filia misji mariannhillskiej założona w roku 1886. Por. AMM - Rzym, biogram: Pater Hyacinth (Peter) Salomon.

${ }^{35}$ O. Jacek był przełożonym tej stacji. Pierwotnie Mariathal nie była stacją misyjną ale tylko miejscem zatrzymań misjonarzy w czasie podróży. Jej otwarcie odbyło się 15 kwietnia 1892 r., po tym jak z Mariannhill przybył (30 marca 1892) o. Jacek. Por. AMM - Rzym, biogram: Pater Hyacinth (Peter) Salomon.

${ }^{36}$ Wiadomości miejscowe z Mariannhill i przyległości. „Niezapominajki” (1892), s. 174. 
li go Umfundusi, czyli ojciec i nauczyciel"37. Ponadto w 1896 r. brał udział w ekspedycji do kraju Maszonów (pn.-wsch. część obszaru dzisiejszego Zimbabwe), na otrzymaną od Cecila Rhodesa ${ }^{38}$ w 1894 r. farmę. Miał tam założyć nową stację misyjną Triashill. Z inicjatywy o. Salomona otrzymała ona nazwę pod wezwaniem Świętej Trójcy, tak samo jak jego kościół parafialny w Nowej Wsi Książęcej. Jednak w związku z powstaniem ludu Maszona przeciwko Brytyjczykom misjonarze zmuszeni byli opuścić tę misję ${ }^{39}$. W $1897 \mathrm{r}$. został posłany do Johannesburga $^{40}$, gdzie przez kilka lat pełnił obowiązki duszpasterza Polonii i Afrykanów pracujących w kopalniach złota. To właśnie tu, w dzielnicy Braamfontein zorganizował polską parafię ${ }^{41}$. „Wybitny znawca dziejów Kościoła katolickiego w południowej Afryce, irlandzki oblat John E. Brady, pisał na ten temat: Wielebny ojciec trapista polskiej narodowości Hyacinth przyjechat do Johannesburga, aby utworzyć tam polska parafię. Pierwotnie miała ona znajdować sie $w$ Booysens w pobliżu kopalni złota Robinson Deep Mine, ale faktycznie rozpoczęła działalność w Braamfontein, gdzie w 1896 r. siostry ze Zgromadzenia Świę-

${ }^{37}$ A. Żukowski, $W$ kraju złota i diamentów, dz. cyt., s. 94; por. tenże, Udział Polaków w założeniu Misji Mariannhillskiej w Natalu, w Afryce Poludniowej, dz. cyt., s. 408.

${ }^{38}$ Cecil John Rhodes, syn pastora, urodzony 5 lipca 1853 r. w angielskim Hertfordshire, przyjechał do Natalu, by leczyć gruźlicę. Był to okres odkryć złoży rudy złota. Cecil Rhodes przez nabycie kilku takich złoży w 19 roku życia zapewnił sobie niezależny byt materialny. Po skończeniu studiów w Anglii powrócił do Kraju Przylądkowego i nawiązał stosunki z towarzystwem akcyjnym De Beer Company. Razem z nim kupił kilka kopalń diamentów i wkrótce zyskał sobie imię obrotnego finansisty. Po objęciu w 1890 r. stanowiska premiera Kraju Przylądkowego, intrygami i przemocą zdobył ziemie na północ od Limpopo, należące do ludów Matabele i Maszona, a na mocy specjalnego królewskiego przywileju stworzył dwa prywatne państwa: Północną i Południową Rodezję (dzisiejsze Zambia i Zimbabwe). Na ruinach królewskiego kraalu (zagrody) Lobenguli w Bulawayo, Rhodes zbudował dom rządowy, powytyczał ulice i place dając w ten sposób początek nowemu miastu. Zmarł 26 marca 1902 r. Por. J. Krzyszkowski, S. Hankiewicz, Polska misja w Afryce. Prefektura Apostolska Brokenhill, Kraków 1927, s. 25-26.

${ }^{39}$ Por. AMM - Rzym, biogram: Pater Hyacinth (Peter) Salomon; por. także, A. Żukowski, W kraju złota i diamentów, dz. cyt., s. 94; por. tenże, Udzial Polaków w założeniu Misji Mariannhillskiej w Natalu, w Afryce Poludniowej, dz. cyt., s. 408.

${ }^{40}$ Por. AMM - Rzym, biogram: Pater Hyacinth (Peter) Salomon; por. także, A. Żukowski, $W$ kraju złota i diamentów, dz. cyt., s. 94. Mylnie prezes Rady Polonii Afryka Południe Edward J. de Virion podaje rok 1890 ponieważ w tym czasie o. Jacek pracował na stacjach: Reichenau i Mariathal, nie mając jeszcze święceń kapłańskich, które otrzymał dopiero w roku 1892. Por. A. Żukowski, Polacy w kraju Springboka do r. 1910, dz. cyt., s. 118.

${ }^{41} \mathrm{~W}$ spisie prefektury apostolskiej w Transwalu z 1899 r. figuruje parafia Polish and Native Mission, nad którą opiekę sprawował m.in. o. Hjacent Salomon. A. Żukowski, W kraju złota i diamentów, dz. cyt., s. 95; por. tenże, Polacy w kraju Springboka do r. 1910, dz. cyt., s. 119; Polonia w Afryce Poludniowej, dz. cyt., s. 183; Geneza, rozwój oraz aktywność Polonii poludniowoafrykańskiej, Biuletyn Polskiego Towarzystwa Afrykanistycznego Afryka (1998) nr 7, s. 89; Wkład Polaków w rozwój Kościoła katolickiego w Afryce poludniowej, dz. cyt., s. 28; Polacy w Afryce Południowej, dz. cyt., s. 38; por. także, F. Bernaś, dz. cyt., s. 101-106. 
tej Rodziny otworzyty szkołę"42. Oficjalne otwarcie parafii nastapiło w 1899 r. i podobnie jak stacja w Rodezji otrzymała nawę pod wezwaniem Świętej Trójcy $^{43}$. Ojciec Salomon czynił również starania, żeby założyć odrębną polską misję na co otrzymał zgodę kard. Mieczysława Ledóchowskiego, prefekta Kongregacji Rozkrzewiania Wiary w latach $1892-1902^{44}$. Niestety malaria, cukrzyca a następnie śmierć położyły kres jego staraniom. Zmarł w Wielką Sobotę 2 kwietnia 1904 r. w wieku 37 lat $^{45}$. Został pochowany następnego dnia w Niedzielę Zmartwychwstania Pańskiego.

Ojciec Anzelm Skotnik ${ }^{46}$ urodził się 19 stycznia 1855 r. w Dziadowej Kłodzie pod Sycowem (dzisiaj województwo dolnośląskie). Z zawodu był szewcem. Do Afryki przybył 24 stycznia 1882 r., czyli prawie rok przed założeniem misji mariannhillskiej. Profesję zakonną złożył 8 września 1884 r. W latach 1884-1885 pracował wśród polskich rolników w Afryce. 22 marca 1890 r. bp Karol Jolivet OMI wyświęcił go na diakona ${ }^{47}$. Do roku 1892 pełnił funkcję redaktora „Niezapominajki" ${ }^{48}$. Na łamach tegoż pisma poinformował czytelników o decyzji przełożonych co do dalszej jego posługi w zgromadzeniu. „Powołany pismem Przewielebnego Opata z dnia 4 lipca br. do klasztoru w Afryce składam tak Czcigodnemu Duchowieństwu, jako też wszystkim Przezacnym Dobroczyńcom serdeczne Bóg zapłać za wszystkie jałmużny na korzyść misji w Mariannhill. Pamiętać będę o Wszystkich przy każdej Mszy Św. (...) Polecając się łaskawej przed Bogiem pamięci, załączam raz jeszcze serdeczne Bóg zapłać"49. O. Anzelm był wielkim patriotą i miłośnikiem przyrody. Tuż przy Mariannhill założył obszerny las z importowanych gatunków drzew, który stanowił jedną z najpiękniejszych ozdób w całej okolicy. Do tej pracy miał tylko kilku nieletnich chłopców jako pomocników. Dzieło swojego życia - stwarzanie ogrodów i lasów wokół Mariannhill - rozpoczął w końcu 1903 r. Przedsięwzięcie to szczegółowo opisał w artykule zamieszczonym w „Vergissmeinnicht” z 1908 r. zatytułowanym. Die

${ }^{42}$ A. Żukowski, Udzial Polaków w założeniu Misji Mariannhillskiej w Natalu, w Afryce Poludniowej, dz. cyt., s. 408.

${ }^{43}$ Por. A. Żukowski, $W$ kraju złota i diamentów, dz. cyt., s. 113.

${ }^{44}$ Por. A. Miotk, Aż na krańce świata. Popularna historia misji, Warszawa 2005, s. 162; por. także, E. Śliwka, Formy zaangażowania Kościoła katolickiego w Polsce okresu międzywojennego $w$ dzieło misyjne, „Animator. Biuletyn misyjno-pastoralny” (1992) nr 1, s. 142-143.

${ }^{45}$ Por. AMM - Rzym, biogram: Pater Hyacinth (Peter) Salomon; por. K. Kowalewski, dz. cyt., s. 356-357; por. J. Kępiński, dz. cyt., s. 223; por. A. Żukowski, Polacy w kraju Springboka do r. 1910, dz. cyt., s. 119; por. tenże, $W$ kraju złota i diamentów, dz. cyt., s. 94-95; Udział Polaków w założeniu Misji Mariannhillskiej w Natalu, w Afryce Poludniowej, dz. cyt., s. 408.

${ }^{46}$ AMM - Rzym, biogram: Pater Anselm (Johann) Skotnik.

${ }^{47}$ J. Kuropka, Z misja do Afryki, „Gazeta Sycowska” 19 października 2005, s. 6.

${ }^{48}$ Było to pismo poświęcone działalności misyjnej oo. trapistów w Mariannhill, w południowej Afryce.

${ }^{49}$ Dotychczasowy redaktor ..., „Niezapominajki” (1892), s. 192. 
Waldanlage in Mariannhill ${ }^{50}$. Ponadto był także wziętym i lubianym spowiednikiem $^{51}$. Zmarł 20 października 1921 r. w Mariannhill ${ }^{52}$. „Wiadomości Misyjne” po jego śmierci napisały o nim: „Niestrudzony w pracy i modlitwie, przejęty na wskroś gorącym duchem kapłańskim i zakonnym, który się wszystkim udzielał, z budującą cierpliwością znosił ciężką chorobę (rak żołądka); do ostatniej chwili pracował w introligatorni, by przysporzyć Misji pożytku. Tak wytrwała wierność niezawodnie niepospolitą w Bogu znalazła nagrodę"53.

Ojciec Ansgar Szczygieł ze Starogrodu na Pomorzu w opinii swojego współbrata Klaudiusza Kowalewskiego „był bardzo gorliwym i popularnym misjonarzem. U tubylców cieszył się wielkim zaufaniem i wszyscy lubili go i kochali jak ojca. Również i w zgromadzeniu naszym zażywał wielkiego poważania"54. Był kandydatem na następnego opata misji mariannhillskiej. Piastował funkcję ojca przełożonego na stacji w Lourdes (od 1891 r.). Jednakże przedwczesna śmierć przekreśliła jego nominację. Zmarł w $1896 \mathrm{r}$. na tyfus ${ }^{55}$. O tym jak wielkie było przywiązanie miejscowej ludności do o. Szczygła świadczy opis ich zachowania podczas jego pogrzebu. „Na jego pogrzebie był lament i płacz tubylców tak wielki, że nad stratą ukochanego Baba - ojca - na ziemię się rzucali”"56.

Brat Rustyk Hajduga ${ }^{57}$ z Rudy Śląskiej koło Bytomia nowicjat w Mariannhill rozpoczął w grudniu 1883 r. Po 4-letniej pracy w misji wyjechał do Europy w celu szukania nowych powołań. Akcję tę skoncentrował głównie na Górnym Śląsku a we Wrocławiu prowadził działalność wydawniczą. Stamtąd rozwinął szeroką akcję propagandową na rzecz misji mariannhillskiej, na obszarze całego Śląska m.in. zbierał datki na misję oraz rozprowadzał publikacje misyjne ${ }^{58}$ „znano go i w Krakowie, szczególnie u Księży Misjonarzy na Kleparzu i u oo.

${ }^{50}$ Por. list wikariusza generalnego, Dietmara Seubert'a, Generalate of Mariannhill Mission in Rome z 26 VI 1989 r. do A. Żukowskiego, autora książki $W$ kraju złota i diamentów dz. cyt. s. 96.

${ }^{51}$ Por. K. Kowalewski, dz. cyt., s. 357.

${ }^{52}$ Por. A. Żukowski, $W$ kraju złota i diamentów, dz. cyt., s. 96; por. także, Drobne wiadomości misyjne, „Wiadomości Misyjne” (1922), s. 44; por. także, Sylwetki Misjonarzy z Mariannhill. O. Anzelm Skotnik CMM (1855-1921), „Wiadomości z Mariannhill” (2004) nr 2, s. 11. Br. Klaudiusz Kowalewski, por. K. Kowalewski, dz. cyt., s. 357, a za nim Jerzy Kępiński, por. J. Kępiński, dz. cyt., s. 222, mylnie jako rok śmierci o. Anzelma podają 1922.

${ }^{53}$ Drobne wiadomości misyjne, dz. cyt., s. 48.

${ }^{54}$ K. Kowalewski, dz. cyt., s. 356.

${ }^{55}$ Tamże; por. także, A. Żukowski, Polacy w kraju Springboka do r. 1910, dz. cyt., s. 120; por. tenże, $W$ kraju złota i diamentów, dz. cyt., s. 96; Udział Polaków w założeniu Misji Mariannhillskiej w Natalu, w Afryce Poludniowej, dz. cyt., s. 409; por. także, J. Kępiński, dz. cyt., s. 221.

${ }^{56}$ K. Kowalewski, dz. cyt., s. 356.

${ }^{57}$ AMM - Rzym, biogram: Bruder Rusticus Hajduga.

${ }^{58}$ Por. A. Żukowski, Polacy w Kraju Springboka do r. 1910, dz. cyt., s. 119; por. tenże, $W$ kraju złota i diamentów, dz. cyt., s. 95; Udział Polaków w założeniu Misji Mariannhillskiej w Natalu, w Afryce Poludniowej, dz. cyt., s. 409; por. także, K. Kowalewski, dz. cyt., s. 357; por. także, J. Kępiński, dz. cyt., s. 222. 
karmelitów na Piasku”59. W tym czasie br. Hajduga udzielił redaktorowi „Misji Katolickickich" ks. Marcinowi Czermińskiemu ${ }^{60}$ wywiadu na temat Polaków pracujących w misji mariannhillskiej. Wywiad ten został opublikowany na łamach „Misji Katolickich” w 1889 roku $^{61}$ oraz w pracy Czermińskiego pt. „Szkice cywilizacyi (sic!) Afryki południowej” w roku $1890^{62}$. Z Polski wyjechał do Stanów Zjednoczonych. Tam na przełomie XIX i XX zajmował się organizacją filii misji mariannhillskiej w Detroit oraz redagował miesięcznik „Vergissmeinnicht”. Był także twórcą angielskiej wersji tego czasopisma przeznaczonego dla trapistów i innych osób zainteresowanych tą tematyką w Stanach Zjednoczonych. Pod koniec życia jako przedstawiciel misji trafił do Linzu w Austrii ${ }^{63}$, gdzie zmarł w roku 1921 mając 68 lat $^{64}$. Po jego śmierci, we wspomnianym periodyku „Vrgissmeinnicht", napisano: Viel hat er gewirkt für Gottes Ehre und Menschen seelen Heil in Afrika und Europa ${ }^{65}$.

Brat Bartłomiej Stenzel (1859-1942), imię zakonne Serwacy. Podobnie jak wspomniany już o. Jacek Salomon pochodził z Nowej Wsi Książęcej koło Bralina. Do klasztoru w Mariannhill wstapił 23 IV 1884 r., w wieku 25 lat. Śluby wieczyste złożył 19 IX 1890 r. W misji mariannhillskiej pracował jako kowal na stacji misyjnej Częstochowa. Przez swoją pracę zawodową zyskał sobie uznanie mieszkańców. Brat Serwacy rąbał drewno, kosił łąki oraz zbierał zboże. Ponadto opiekował się chorymi i czuwał przy umierających. Na stacji misyjnej Częstochowa przebywał aż do końca swoich dni. Gdy nadeszła jego godzina, cierpiącego zapytano czy nie ma dość, odpowiedział: „Ja powinienem jeszcze więcej cierpieć!" Zmarł 6 lipca 1942 r. ${ }^{66}$.

Brat Bothlof Pawlica (1859-1935) ${ }^{67}$ pochodził z Bielszowic koło Rudy Śląskiej. Do 28 roku życia na Górnym Śląsku zarabiał jako górnik. W 1887 r. po przeczytaniu w kalendarzu mariannhillskim wezwania o nowe powołania opuścił

${ }^{59}$ K. Kowalewski, dz. cyt., s. 357.

${ }^{60}$ Jako redaktor „Misji Katolickich” w latach 1889-1919 nawiązał szereg kontaktów z misjonarzami w różnych częściach świata. Podczas licznych jego podróży gromadził wiele materiałów, które publikował m.in. w „Misjach Katolickich” a także w postaci książek. Por. J. Knopek, Czermiński Marcin, [hasło w:] Encyklopedia Polskiej Emigracji i Polonii, dz. cyt., s. 374.

${ }^{61}$ OO. Trapiści w Natalu, ,Misje Katolickie” (1889), s. 235-245, 282-287, 308-314, 343-348.

${ }^{62}$ Por. J. Kępiński, dz. cyt., s. 222.

${ }^{63}$ Por. A. Żukowski, W kraju złota i diamentów, dz. cyt., s. 95; por. tenże, Udziat Polaków w założeniu Misji Mariannhillskiej w Natalu, w Afryce Poludniowej, dz. cyt., s. 409; por. także, K. Kowalewski, dz. cyt., s. 357.

${ }^{64}$ „Wiadomości Misyjne” (1922) nr 7, s. 56; por. także, K. Kowalewski, dz. cyt., s. 357.

${ }^{65} \mathrm{~W}$ wolnym tłumaczeniu można oddać to słowom: „Dużo on zdziałał dla chwały Bożej i dobra dusz ludzkich w Afryce i Europie”. Por. A. Żukowski, Udział Polaków w założeniu Misji Mariannhillskiej w Natalu, w Afryce Poludniowej, dz. cyt., s. 409.

${ }^{66}$ Por. AMM - Rzym, biogram: Bruder Serwatius Stenzel.

${ }^{67}$ AMM - Rzym, biogram: Bruder Bothlof Pawlitza. 
rodzinne strony i wstapił do zgromadzenia ${ }^{68}$. W pierwszych latach życia zakonnego służył misji jako robotnik rolny oraz w wielu innych zajęciach. Następnie jako młynarz pracował na stacjach w Rychnowie, Częstochowie, Lourdes, a na końcu w św. Izydorze w okolicach Doliny Maryi. Był specjalistą od budowy i eksploatacji młynów. Oprócz kamieni, jakie się znajdowały w jego młynie utrzymywał w porządku także kamienie młyńskie innych stacji ${ }^{69}$. „Jako młynarz służył ponadto swą pracą utrzymaniu ciała i wyżywieniu licznych misjonarzy, chrześcijan i tubylców. Wraz z innymi starał się o chleb powszedni setek i tysięcy, zamieniając kukurydzę i zboże na mąkę"70. To dzięki niemu wypiekano kilka milionów hostii. $\mathrm{Z}$ upodobaniem przez dłuższy czas pełnił także służbę ministranta, kościelnego i dzwonnika. „Przed wyjazdem do Johannesburga był zaangażowany w utworzenie czysto polskiej stacji misyjnej w Natalu, której istnienie okazało się jednak krótkotrwałe"71. W Johannesburgu obok o. Jacka Salomona prowadził działalność duszpasterską wśród polskich robotników sezonowych i Afrykanów pracujących w kopalniach złota ${ }^{72}$. Po jego śmierci tak o nim wspominano: „Brat Botholf niemal przez pół wieku okazywał się wiernym zakonnikiem dobrego ducha i prawdziwej pobożności. Ora et labora, porządek punktualny i dokładność stały się mu drugą natura. Szczególnie budującymi były jego umiłowanie ubóstwa zakonnego jego wytrwałość w modlitwach i odwiedzaniu kościoła, także w najwcześniejszych godzinach zimnych poranków zimowych. Jutrznię, Mszę św. i Komunie św. cenił brat Botholf nader wysoko"73. Gdy miał 74 lata i zdrowie nie pozwoliło mu na dalszą pracę wycofał się z misyjnego posterunku. Zmarł 16 marca 1935 r. w 76-tym roku życia a 46-tym profesji zakonnej, na trzy dni przed uroczystością św. Józefa ${ }^{74}$.

Brat Emanuel Kopiec (1860-1943) ${ }^{75}$, imię zakonne Lupus. Do Mariannhill przybył w roku $1887^{76}$. Przez prawie 50 lat prowadził garbarnię, warsztat galanteryjny oraz rymarski. „Ze skór dzikich zwierząt produkował różne wyroby skórzane. Przynosiły one największe dochody klasztorowi" "77. Zatrudniał w tych warsztatach 30-40 robotników, względnie uczniów. Pod koniec życia zarządzał już tylko garbarnią. Pomagał mu przy tym brat Paweł Lebson, również Polak z Królewskiej

${ }^{68}$ Por. A. Żukowski, W kraju złota i diamentów, dz. cyt., s. 96; por. tenże, Udział Polaków w założeniu Misji Mariannhillskiej w Natalu, w Afryce Poludniowej, dz. cyt., s. 409.

${ }^{69}$ Por. Niezabudka cmentarna, „Wiadomości Misyjne” (1935), s. 168.

70 Tamże.

${ }^{71}$ A. Żukowski, Udział Polaków w założeniu Misji Mariannhillskiej w Natalu, w Afryce Południowej, dz. cyt., s. 409.

${ }^{72}$ Por. A. Żukowski, $W$ kraju złota i diamentów, dz. cyt., s. 96.

${ }^{73}$ Niezabudka cmentarna, dz. cyt., s. 168.

${ }^{74}$ Por. tamże.

${ }^{75}$ AMM - Rzym, biogram: Bruder Lupus Kopietz.

${ }^{76}$ Por. A. Żukowski, Polacy $w$ kraju Springboka do r. 1910, dz. cyt., s. 121; por. tenże, W kraju złota i diamentów, dz. cyt., s. 96.

${ }^{77}$ Tenże, $W$ kraju złota i diamentów, dz. cyt., s. 96. 
Huty na Górnym Śląsku ${ }^{78}$. Brat Lupus był bardzo przywiązany do Polski. W jego biogramie $\mathrm{z}$ akt personalnych znajduje się następujący zapis: „chętnie posługiwał się mową polska, modlił się prawie wyłącznie z polskich modlitewników, czytywał właściwie tylko polskie książki. (...) Był mocno przywiązany do kultu Matki Boskiej Częstochowskiej oraz św. Anny z Piekar Śląskich"79.

Brat Tomasz Kłosak (1863-1928) ${ }^{80}$, imię zakonne Teofil, pochodził ze wsi Biskupice na Śląsku. Do misji mariannhillskiej wstąpił po śmierci żony, mając 33 lata. „Przez 40 lat pracował na misjach w Natalu oraz w dzisiejszym Zimbabwe, gdzie był współzałożycielem wielu placówek" "

Do wyjątkowych ludzi, którym nie trudno było poznać i nauczyć się miejscowych języków należał o. Maurus Józef Kalus (1874-1946) ${ }^{82}$, Górnoślązak. Do Mariannhill przybył w roku 1898. Święcenia kapłańskie otrzymał w $1906 \mathrm{r}^{83}$. „Podziwiany za zdolności lingwistyczne został uznany za wybitnego znawce miejscowych języków" ${ }^{4}$. Mówił i pisał w trzech narzeczach tubylczych. „Przetłumaczył na język Zulusów m.in. Pismo Święte, katechizm, modlitewniki i śpiewniki, (...) w języku Sotho wydał katechizm i opowieści biblijne, które (...) za swój wysoki poziom zyskały nawet uznanie oblatów z Lesotho, pracujących wśród ludu Basuto od dziesięcioleci" "85. Jednocześnie dla nowo założonych zakonów sióstr i braci tubylczych przetłumaczył konstytucje na język zuluski oraz kilka broszurek do nabożeństwa ${ }^{86}$. Był także kapelanem klasztoru sióstr dominikanek w Umsinsini. Przez 26 lat pracował na różnych stacjach misyjnych m.in. Mariazell, Marianlinden, Hardenberg, i St. Patrick`s ${ }^{87}$. Od czasu do czasu wyjeżdżał również na inne stacje misyjne gdzie głosił rekolekcje braciom i siostrom zakonnym zarówno europejskim jak i tubylczym ${ }^{88}$.

${ }^{78}$ Por. K. Kowalewski, dz. cyt., s. 358; por. tenże, Nieco o rodakach naszych w Misji Mariannhillskiej, „Wiadomości Misyjne” (1933) nr 7, s. 72; por. także, Wieczne śluby w Mariannhillu, „Wiadomości Misyjne” (1920), s. 89.

${ }^{79}$ AMM - Rzym, biogram: Bruder Lupus Kopietz.

${ }^{80}$ AMM - Rzym, biogram: Bruder Theophil Klosak.

${ }^{81}$ Tamże.

${ }^{82} \mathrm{~W}$ aktach personalnych misji mariannhillskiej oraz publikacjach A. Żukowskiego o. Maurus Kalus uznawany jest za brata. Natomiast „Misje Katolickie” oraz „Wiadomości Misyjne” piszą o nim jako o ojcu, por. K. Kowalewski, „Polski” Mariannhill..., dz. cyt., s. 357; por. tenże, Nieco o rodakach naszych w Misji Mariannhillskiej, dz. cyt., s. 72; por. także, Misja Mariannhillska w czasie wojny światowej, „Wiadomości Misyjne” (1922), s. 2-3.

${ }^{83}$ Por. J. Kępiński, dz. cyt., s. 223.

${ }^{84}$ A. Halemba, dz. cyt., s. 38.

${ }^{85}$ Por. A. Żukowski, $W$ kraju złota i diamentów, dz. cyt., s. 96-97; por. tenże, Udział Polaków w założeniu Misji Mariannhillskiej w Natalu, w Afryce Poludniowej, dz. cyt., s. 409-410.

${ }^{86}$ Por. K. Kowalewski, „Polski” Mariannhill..., dz. cyt., s. 357-358.

${ }^{87}$ Por. A. Żukowski, W kraju złota i diamentów, dz. cyt., s. 97; por. tenże, Udział Polaków w założeniu Misji Mariannhillskiej w Natalu, w Afryce Poludniowej, dz. cyt., s. 410.

${ }^{88}$ Por. K. Kowalewski, „Polski” Mariannhill..., dz. cyt., s. 357-358. 
Drugim obok o. Maurusa Kalusa ojcem, który nie miał trudności z nauką miejscowych języków był o. Angelik Konieczka ${ }^{89}$, Wielkopolanin. O. Angelik był misjonarzem na stacji Maria-Ratschitz ${ }^{90}$ oraz tymczasowo pełnił duszpasterstwo na stacji misyjnej poświęconej św. Franciszkowi Ksaweremu, leżącej na obszarze misyjnym ojców oblatów ${ }^{91}$.

Trzecim z nich był pochodzący z Opola o. Hieronim Łyszy. Pracował on na stacjach misyjnych Lourdes, Częstochowa oraz Rychnowo. Wystapił z Kongregacji Misjonarzy z Mariannhill i jako ksiądz diecezjalny pracował pod księdzem biskupem mariannhillskim. W misji mariannhillskiej zasłynął jako bardzo dobry kaznodzieja ${ }^{92}$.

Brat Teodor Koralczak ${ }^{93}$ (1882-1935) swoją pracę w Mariannhill rozpoczął na początku XX w. Osiągnął on duże sukcesy w dziedzinie edukacji. Posiadał również zdolności muzyczne dzięki, którym wprowadził do obrzędów religijnych wiele elementów muzycznych ${ }^{94}$.

Brat Teofil Jośko urodzony 8 lutego 1904 r. w Miławie na Śląsku do zgromadzenia wstąpił 5 listopada 1926 r. Pierwsze śluby złożył 12 maja 1929 r. W misji mariannhillskiej pracował jako kowal i ślusarz. Bardzo dobrze znał się na rzemiośle malarskim. O błogosławionej działalności i śmierci na nowo założonej stacji misyjnej, poświęconej Matce Bożej Pośredniczce Łask, jeden z tamtejszych misjonarzy napisał m.in.: „Niestety nowa stacja misyjna zabrała już ofiarę przez zejście naszego - jakże dzielnego - br. Teofila. (...) Br. Teofil przybył do nas w święto Chrystusa Króla r. ub. (25 października 1936 - K.P.) ażeby wybudować szpital życzony przez rząd, chociaż sami nie mieliśmy jeszcze dachu nad głową. Okazywał w ogóle gorliwość bardzo dużą, tak co się tyczy zbawienia dusz, jak i tego, aby poszczególne stacje postawić na nogi. Aczkolwiek nie wyuczył się właściwie malarstwa, znał się na nim wyśmienicie. Marzeniem jego było zawsze odstawiać robotę solidną. Gdy w lutym szpital już był gotów, zaczął nowy budynek dla nas abyśmy także nie tak mocno cierpieli w tym klimacie. Mieszkaliśmy wciąż jeszcze w chatkach blaszanych. - Niestety Braciszek uczynny nie miał już dokończyć budowli, ponieważ wezwał go Anioł śmierci"95.

\footnotetext{
${ }^{89}$ J. Knopek błędnie podaje go jako siostrę zakonną. Por. J. Knopek, Afryka Południowa, duszpasterstwo, dz. cyt., s. 37.

${ }^{90}$ Por. K. Kowalewski, „Polski” Mariannhill..., dz. cyt., s. 358.

${ }^{91}$ Por. Na śladach opata Franciszka, dz. cyt., s. 47.

${ }^{92}$ Por. K. Kowalewski, „Polski” Mariannhill..., dz. cyt., s. 358; por. także, M. Kalus, Misje w kraju misyjnym, „Wiadomości Misyjne” (1929), s. 1.

93 „Wiadomości Misyjne” podają Karolczak, por. Gdy kwitnqć będzie wino..., „Wiadomości Misyjne" (1936), s. 98.

${ }^{94}$ Por. A. Żukowski, W kraju złota i diamentów, dz. cyt., s. 97; por. także, K. Kowalewski, Nieco o rodakach naszych $w$ Misji Mariannhillskiej, dz. cyt., s. 72.

${ }^{95}$ Wcześnie skończony przeżył lat wiele, „Wiadomości Misyjne” (1937), s. 164.
} 
Jako przyczynę jego śmierci podano malarię i stosa pacierzowego, najgorszą w swoim rodzaju. Zmarł w wieku 33 lat $^{96}$.

Jednym z najbardziej znanych i zasłużonych misjonarzy mariannhillskich, zwany ,prawą ręką” ojca założyciela Franciszka Pfannera był brat Nivard Streicher $^{97}$. Jako świetny inżynier i budowniczy znany był w całej południowej Afryce. Dzięki temu podczas pierwszej wojny światowej, gdy pozostali współbracia byli internowani i mieli zakaz podróżowania poza swój okręg działania, on miał pozwolenie podróżowania po całym $\mathrm{kraju}^{98}$. Sam własnymi siłami i pomocniczymi, złożonymi z miejscowej ludności, wystawił niemal wszystkie okazałe kościoły misji. Zmarł w 1927 r. ${ }^{99}$.

Brat Walerian Śmieja (1851-1928) przez 30 lat pełnił funkcję kierownika Zastępstwa Misji Mariannhillskiej we Wrocławiu. W 1922 roku na polecenie przełożonych został przeniesiony do Mariannhill. Żegnając się na łamach „Wiadomości Misyjnych" dziękował czytelnikom za pomoc i życzliwość jaką okazywali mu przez ten długi okres. Pisał: „Wywiązując się z miłego obowiązku, wyrażam niniejszym serdeczne podziękowanie wszystkim Dobrodziejom, Pomocnikom i Przyjaciołom Misji, w szczególności Kapłanom, zgromadzeniom zakonnym, literackim współpracownikom, i wszystkim i każdemu z osobna tym, którzy choćby najdrobniejszymi ofiarami i datkami wspierali Misje i pomagali ratować dla nieba dusze pogan. Zarazem proszę, by nie zmienioną życzliwość zachowali i nadal dla naszej Misji i równym zaufaniem darzyli nowego Kierownika Zastępstwa Misji, którego Przełożeni ustanowią. Korząc się Bogu, ponownie wyrażam wszystkim, jak wyżej, rzetelną cześć i serdeczne podziękowanie, z prośbą o modlitwę"100. Brat Walerian zmarł w Mariannhill w roku 1928 mając 77 lat.

Br. Jan ze Śląska do Mariannhill przybył w 1882 r. Przyczynił się on do założenia wielu stacji misyjnych. W misji mariannhillskiej pracował m.in. jako kucharz. Mimo podeszłego wieku bardzo dobrze jeździł konno, dzięki temu - jak wspominał jego współbrat o. Innocenty - „nie jeden starzec lub staruszka, wpierw poganka, zawdzięczają jego zabiegom, że w ostatniej jeszcze godzinie otrzymali chrzest św." 101.

Ponadto w południowej Afryce pracowali także inni Polacy. Przechowało się po nich mniej wiadomości. Ponieważ ich wkład w rozwój misji mariannhillskiej był również znaczący, dlatego podaję krótkie informacje, jakie udało się o nich zebrać.

\footnotetext{
96 Por. tamże.

${ }^{97}$ Por. A. Żukowski, W kraju złota i diamentów, dz. cyt., s. 94.

${ }^{98}$ Por. Misja Mariannhillska w czasie wojny światowej, dz. cyt., s. 2.

99 Por. 50-rocznica założenia klasztoru Mariannhill, dz. cyt., s. 21.

${ }^{100}$ Do Szanownych Czytelników, „Wiadomości Misyjne” (1922), s. 80.

${ }^{101}$ Przygody misyjne wśród Bazutów, ,Wiadomości Misyjne” (1922), s. 74.
} 

roku $^{102}$.

Brat Benigny Loga (Górnoślązak) był mistrzem krawiectwa. Zmarł w 1938

Brat Bazyljusz Sowka (Górnoślązak) pracował na stacji misyjnej Monte Cassino w Rodezji ${ }^{103}$.

Ojciec Tomasz Respondek pełnił funkcję nauczyciela filozofii w Mariannhill. Następnie pracował w Zastępstwie Misji Mariannhillskiej w KatowicachBogucicach jako kierownik tejże misji w Polsce ${ }^{104}$.

Brat Konstanty Mielewski po śmierci brata Waleriana Śmieji objął funkcję kierownika Zastępstwa Misji Mariannhillskiej oraz redaktora „Wiadomości Misyjnych”. Na polecenie przełożonych został on przeniesiony z Mariannhill, do pracy w Polsce.

W Mariannhill, pracował również brat Klaudiusz Kowalewski. Dzięki jego listom czytelnicy „Wiadomości Misyjnych”, „Misji Katolickich” oraz innych wydawanych w tym czasie czasopism misyjnych, mogli śledzić pracę polskich misjonarzy w południowej Afryce. To właśnie z jego relacji najwięcej dowiadujemy się o Polakach pracujących w misji mariannhillskiej, rodzajach ich pracy, problemach z jakimi się borykali oraz sukcesach jakie osiagali na polu misyjnym.

O innych naszych rodakach, którzy pracowali w misji mariannhillskiej mówi wierszowany list z 1933 roku autorstwa wyżej wspomnianego brata Klaudiusza Kowalewskiego.

„(...) Tobie wiadomo mily przyjacielu,

Że w Marianhilu tu Polaków wielu,

Co lubią pisma i chętnie czytają,

Przez co pociechę i pożytek mają.

(...) Chory Brat Klaudy zaś byłym malarzem,

Zwinny Brat Gosbert do zębów technikiem,

Brat Doroteusz, wszędy pomocnikiem.

Brat Wyluś w oficynie zajęty piśmiennictwem,

Brat Eugen zaś, w ogrodzie warzywem, sadownictwem,

Benignus Brat, jest „Um Afryki” ${ }^{105}$ ekspedjenetm,

(...) Brat Łucjan nawet głośnym wkoło zegarnikiem,

A przy tym bardzo sławnym, pilnym jest bartnikiem,

${ }^{102}$ Por. Informacja pod zdjęciem w: „Wiadomości Misyjne” (1939), s. 4.

${ }^{103}$ Por. Informacja pod zdjęciem w: „Wiadomości Misyjne” (1930), s. 37.

${ }^{104}$ Por. Informacja pod zdjęciem w: „Wiadomości Misyjne” (1939), s. 27.

${ }^{105}$ Tygodnik katolicki wydawany w języku zuluskim, szeroko rozpowszechniony między miejscową ludnością. W tym czasie pismo to było jednym z najważniejszych środków propagandowych misji we wszystkich częściach południowej Afryki. Por. 50-rocznica założenia klasztoru Mariannhill, dz. cyt., s. 21. 
(...) Brat Magnus, jako stary, długą brodę głaszcze;

A ku temu to dusza wszystkim bardzo szczera,

A już gazety polskie, to niemal pożera,

(...) Brat Mateusz, szpitalnik, sam łyżki, talerze,

Myje, pełniąc swój urząd starannie i szczerze,

Dbając, by jego chorym nic nie brakowało,

Każdemu co należy raczej się dostało.

Mamy pomiędzy nami też Brata Litwina,

Jest to jednakże jego tylko własna wina,

Że hodowlą pszczół także chętnie się zajmuje,

Aż Bratu Łucjanowi interesa psuje.

$\mathrm{Z}$ naszych jest jeszcze kilku czynnych po stacjach,

Boć wiadomo każdemu, jak to na misjach,

Że trzeba iść tam, dokąd Wyżsi iść rozkaża,

W drogę błogosławieństwem z kromką chleba darzą"106.

W wywiadzie przeprowadzonym przez ks. Marcina Czermińskiego brat Rustyk Hajduga wspominał również ojców: Grötschela z Głubczyc, Seltmana z Wrocławia, Beda z Chełmna, Szecika ze Śląska austriackiego oraz braci: Juliusza Cichonia z Piekar, Ludwika i Wacława ze Szczepanowic pod Raciborzem, Konrada i Foksa z Rudy Śląskiej, Efrema z Żernic koło Gliwic, Krawczyka (Malachiasza) oraz Maurycego z Rozdzienia, Aleksandra i Abla z Kłodzka, Karola oraz Kantocha z Zaborza, Januszka z Imietnicy koło Wielkich Strzelec, Piegro z Rudna, Kruka z Lubina oraz Gajewskiego z Imielnika ${ }^{107}$. Ilość wspomnianych Polaków jest zaniżona, gdyż autor wywiadu kończąc wyliczanie misjonarzy napisał, że pracuje tam ,wielu innych, których brat Hajduga nie przypomina sobie nazwisk i pochodzenia" 108 .

\section{POLSKIE SIOSTRY W MISJI MARIANHILLSKIEJ}

W ramach misji mariannhillskiej pracowały także siostry zakonne, dla których o. Franciszek Pfanner powołał Zgromadzenie Sióstr Misjonarek od Drogocennej Krwi. Pierwsze siostry pochodziły z Niemiec, Śląska oraz Chorwacji ${ }^{109}$. Do Natalu przybyły we wrześniu $1885 \mathrm{r}$. Stały się one pionierkami wspomnianego zakonu, który już w 1901 r. liczył 300 sióstr zakonnych. Zadaniem sióstr było organizowanie szkolnictwa dla dziewcząt, pomoc medyczna oraz przygotowywa-

\footnotetext{
${ }^{106}$ K. Kowalewski, Nieco o rodakach naszych $w$ Misji Mariannhillskiej, dz. cyt., s. 72.

${ }^{107}$ Por. M. Czermiński, dz. cyt., s. 100, 102.

108 Tamże, s. 102.

${ }^{109}$ Por. tamże, s. 152.
} 
nie ich do chrztu ${ }^{110}$. „Wśród misjonarek misji mariannhillskiej było niemało Polek"111. Większość sióstr pochodziła ze Śląska.

Siostra Maria Lassak, imię zakonne Klara urodziła się w 1864 r. w Wrzesinie na Górnym Śląsku. Przed wstapieniem do zakonu razem z rodzicami mieszkała na farmie niedaleko drogi, która łączyła Mariannhill z Pinetown. Jej ojciec dzierżawił ziemię uprawną od misji mariannhillskiej. Do zgromadzenia wstapiła w 1885 r., ,należała ona do grupy pierwszych sióstr tego zakonu. W tym czasie była jedyną, która potrafiła posługiwać się językiem zulusów. $Z$ tego też powodu opat Pfanner powierzył jej pieczy szkolnictwo dziewcząt zuluskich" ${ }^{112}$.

W drugiej połowie lat osiemdziesiątych XIX w. do misji mariannhillskiej wstapiły m.in.: Marta Preiss (1864-1920) z Poręby Zaborskiej, Paulina Strzała (1861-1932) z Knorowa koło Gliwic, Agnieszka Kurzawa (1869-1951) z Turków koło Bralina i Joanna Kocurek (1859-1939) z Zabrza. A także Magdalena Piasek z Lublińca, Anna Bednarz z Biskupic, Joanna Łokieć z Rudy, Monika Kniszcz z Nowej Wsi Książęcej oraz Marianna Szeca z Trzebnicy ${ }^{113}$.

Duże zasługi w rozwój misji mariannhillskiej wniosła rodzina Salomonów z Nowej Wsi Książęcej koło Bralina. Do pracy misyjnej w „dalekiej” Afryce zachęcał ich sam o. Pfanner. Poza wspomnianym już wcześniej o. Jackiem członkiniami misji były trzy jego siostry: Katarzyna, Joanna i Franciszka oraz rodzi$\mathrm{ce}^{114}$. W związku $\mathrm{z}$ tym, że rodzina Salomonów wniosła poważny wkład w rozwój misji mariannhillskiej każdy z nich zasługuje na oddzielne potraktowanie ${ }^{115}$.

Ojciec rodziny - Ignacy Salomon urodził się 31 XII 1832 r. w Nowej Wsi Książęcej. Do nowicjatu wstapił w 1888 r. Żona jego - Franciszka w tym samym czasie wstąpiła do sióstr w Mariannhill. Otrzymali imiona zakonne: Spiridion i Casparina. W styczniu 1889 r. oboje wystapili z nowicjatu i z dziewięcioletnią córką Franciszką powrócili do ojczyzny ${ }^{116}$.

Najstarsza córka - Katarzyna urodziła się 29 IV 1869 r. Do Mariannhill przybyła jeszcze przed rodzicami i jako s. Weronika 13 II 1887 r. rozpoczęła nowicjat. Pierwsze śluby złożyła 13 II 1889 r. W misji mariannhillskiej pełniła funkcję generalnej wikariuszki. Zmarła w Mariannhill 21 maja $1941 \mathrm{r}^{117}$

\footnotetext{
${ }^{110}$ Por. A. Żukowski, W kraju złota i diamentów, dz. cyt., s. 97.

${ }^{111}$ Tamże.

${ }^{112}$ Tamże, s. 98.

${ }^{113}$ Por. M. Czermiński, dz. cyt., s. 102-103; por. A. Żukowski, W kraju złota i diamentów, dz. cyt., s. 98.

${ }^{114}$ Por. M. A. Buschgrrd, For a great price. The Story of the Missionary Sisters of the Precious Blood, [bmw] 1990, s. 463-464.

${ }^{115}$ Por. A. Żukowski, $W$ kraju złota i diamentów, dz. cyt., s. 98.

${ }^{116}$ Por. D. Seubert, Familie Salomon (P. Hyacinth), [mps bmrw], s. 1.

${ }^{117}$ Por. tamże.
} 
Młodsza córka - Joanna urodziła się 5 XII 1873 r. ${ }^{118}$. Obłóczyny miała dopiero w październiku 1889 r. po osiagnięciu odpowiedniego wieku, gdyż była za młoda i musiała jeszcze ukończyć szkołę. Jako s. Dorota rozpoczęła nowicjat 3 XI 1889 r. Pierwsze śluby złożyła 8 XII 1891 r. W Mariannhill prowadziła katechezę dla dzieci. Zmarła w Ixopo 19 sierpnia 1953 r. ${ }^{119}$

Najmłodsza z rodzeństwa - Franciszka urodziła się 30 III 1879 r. Po śmierci ojca razem z matką 23 V 1896 r. powróciła do Mariannhill. Jako s. Stanisława 15 VIII 1896 r. rozpoczęła nowicjat i razem z matką 8 XII 1898 złożyła pierwsze śluby zakonne. Zmarła 15 lipca 1963 r. w Ixopo ${ }^{120}$.

Matka rodziny - Joanna urodziła się 1 VI 1838 r. Jak już zostało wspomniane po śmierci męża powróciła do Mariannhill. Jako s. Aletha 8 XII 1896 r. została przyjęta do nowicjatu. Zmarła 25 września 1901 r. w wieku 63 lat w Mariannhill ${ }^{121}$.

Ponadto polskie misjonarki pracowały również w niemieckiej Afryce Południowo-Zachodniej (obecnie Namibia) ${ }^{122}$. Na przełomie XIX i XX wieku zarówno ojcowie, bracia jak i siostry z misji mariannhillskiej stanowili największe skupisko polskich misjonarzy. Ówczesny rząd angielski pokrywał część kosztów podróży przyszłych misjonarzy z Londynu do Durbanu ${ }^{123}$. „W następnych latach liczebność polskich misjonarzy i misjonarek wzrastała, tak że w okresie największego rozwoju działało w tej misji około 30 ojców i braci oraz ponad 40 sióstr"124. Liczba Polaków zaczęła się zmniejszać z chwilą odzyskania przez Polskę niepodległości. Wtedy to Polacy zaczęli wstępować do nowo powstałych zgromadzeń misyjnych na ziemiach polskich ${ }^{125}$. Z relacji brata Klaudiusza Kowalewskiego z roku 1934 dowiadujemy się iż na samej stacji Mariannhill pracował wtedy jeden kapłan oraz szesnastu braci. Poza tym na innych stacjach misyjnych znajdowało się jeszcze dwóch kapłanów i kilku braci ${ }^{126}$.

${ }^{118}$ A. Żukowski błędnie podaje rok 1887 jako jednakowy dla urodzenia Joanny oraz jej młodszej siostry Franciszki. Por. A. Żukowski, $W$ kraju złota i diamentów, dz. cyt., s. 98. Dane podane za AMM wydają się bardziej prawdopodobne, choćby ze względu na późniejsze losy młodszej z sióstr - Franciszki, która w 1889 r. mając 9 lat razem z rodzicami wróciła do Polski. Starsza Joanna w 1889 roku miała obłóczyny. Por. D. Seubert, dz. cyt.

${ }^{119}$ Por. tamże.

${ }^{120}$ Por. tamże.

${ }^{121}$ Por. tamże.

${ }^{122}$ Por. A. Żukowski, Kobiety Polskie w Afryce - przyczynek do monografii problemu, [w:] Losy Polek. IV Sympozjum Biografistyki Polonijnej, Wiedeń 1-2 września 1999, Agata i Zbigniew Judyccy (red.), Lublin 1999, s. 367.

${ }^{123}$ Por. J. Kępiński, dz. cyt., s. 222.

${ }^{124}$ A. Żukowski, $W$ kraju złota i diamentów, dz. cyt., s. 98-99; por. tenże, Udział Polaków w założeniu Misji Mariannhillskiej w Natalu, w Afryce Poludniowej, dz. cyt., s. 410; por. także, J. Kępiński, dz. cyt., s. 222.

${ }^{125}$ Por. tamże.

${ }^{126}$ Por. K. Kowalewski, „Polski” Mariannhill..., dz. cyt., s. 357; por. także, J. Kępiński, dz. cyt., s. 223. 


\section{RODZAJE PRACY MISYJNEJ}

\section{Praca duszpasterska i organizacyjna}

Na przełomie XIX i XX w. udział Polek i Polaków w dziele misyjnym w południowej Afryce był znaczny. W dużej mierze to właśnie dzięki ich heroicznej pracy misja mariannhillska należała do najbardziej rozwiniętych. Jednak żadne dzieło nie rodzi się bez trudu, wysiłku i poświęcenia. Jeden z pierwszych polskich ojców - Anzelm Skotnik - tak oto wspominał początki Mariannhill. „Było to 27 grudnia 1883 , około godziny $1 / 211$ przed południem, gdyśmy z Pinetown tutaj do Mariannhillu ze wszystkim przybyli. Gdyśmy nasze rzeczy z wozów złożyli, a przy tym nasz podróżny ołtarz, uklękliśmy na mariannhillskiej ziemi, także nasz czcigodny Przełożony, O. Franciszek Pfanner, który dzień przedtem przybył. Odmówiliśmy miserere, na to trzy Ojcze nasz, Zdrowaś Mario i Chwała Ojcu itd. na cześć Najświętszej Trójcy i pocałowaliśmy trzy razy ziemię. Potem odprawił O. Franciszek Mszę św. ${ }^{127 \%}$. O. Anzelm opisywał dalej „Po posileniu się wzięliśmy się do wyładowania ciężkich skrzyń z obydwu wozów i ustawiliśmy w jednej linii za ołtarzem, który ustawiony na dwóch skrzyniach, stał przez 6 tygodni na tym samym miejscu. (...) Aby nasze pakunki uchronić przed deszczem zostawił nam jeden osadnik za miernym wynagrodzeniem swoje wielkie płótno wozu. To rozciągliśmy na wszystkie nasze skrzynie. Tam chroniliśmy się w deszczowe dnie i noce. Podczas pogodnych dni sypialiśmy pod gołym niebem. Sienników nie mieliśmy, lecz za to tysiące ślepców (robaczek), które zagnieżdżały się w naszych habitach i wysysały nam krew. Najgorszą była biegunka krwawa. (...) Często przyłączała się do tego straszna febra. Ja sam byłem piastunem chorych a oprócz tego zaopatrywałem zakrystią, lecz ta nie robiła mi wiele kłopotu, bo jeszcze w tym czasie nie była zupełną. $\mathrm{O}$ innych potrzebach i o głodzie, które musieliśmy znosić, wolę zamilczeć. Niektórzy może będą się z tego śmiać; my wtenczas nie śmialiśmy się, lecz cierpieli spokojnie"128.

Misjonarze nie bacząc na wszelkie przeciwności od razu wzięli się do pracy. Jedni kosili, orali, siali inni kopali studnie, stawiali piece piekarskie. Prali bieliznę, gotowali pożywienie jeszcze inni rozpakowywali skrzynie, rozpinali namioty i zwozili drewno ${ }^{129}$. W bardzo krótkim czasie wybudowali szesnaście mil angielskich drogi, dziewięć murowanych mostów oraz dwie murowane tamy ${ }^{130}$. „Żelazna wytrwałość i praca opata i braci w kilka lat zamieniły step w schludna osadę a dziką okolicę w uprawny ogród. Pobudowano kaplice, domy, fabryki, składy, zasadzono sady i plantacje, osuszono miejsca bagniste a suche nawod-

\footnotetext{
${ }^{127}$ A. Skotnik, Pierwsze poczatki Mariannhillu, „Wiadomości Misyjne” (1914), s. 177.

${ }^{128}$ Tamże, s. 177-178.

${ }^{129}$ Por. M. Czermiński, dz. cyt., s. 88.

${ }^{130}$ Por. tamże, s. 96.
} 
niono" 131 . Wszystko to niejako poprzez noc wyrastało z ziemi. „Bracia - rękodzielnicy byli zatrudnieni w zakresie rzemiosła własnego, a robotnicy rolni wśród niejednych rozczarowań doświadczali najlepszej wiedzy swej i umiejętności, ażeby dzikiemu ugorowi afrykańskiemu wydrzeć jakieś ziemiopłody" ${ }^{132}$. Polscy bracia zasłynęli jako znakomici fachowi rzemieślnicy. Prowadzili różnego rodzaju warsztaty: techniczno-dentystyczny, szewski, wozowniczy, siodlarski, zegarmistrzowski, garbarski i inne ${ }^{133}$.

Tubylcy od razu dostrzegli tych białych ludzi, którzy mieli nie tylko biała skórę i czerwone brody, ale nosili również białe ubrania. O. Franciszek Pfanner wspominał: „Gdy się dowiedzieli, żeśmy kupili ziemię, na której mieszkali, a oni tym sposobem naszymi dzierżawcami zostana, cieszyli się, tańczyli i tupali nogami z radości. Ze wszystkich gór i pagórków zbiegali gromadnie i pytali, czy ich domy leżą na gruncie trapistów; gdy im pokazałem granice, które białymi choragwiami ze wszystkich stron kazałem wetknąć, a przekonali się, że ona i ich domostwa obejmuje, cieszyli się niezmiernie, po wielekroć powtarzali uszczęśliwieni łamaną angielszczyzną: you my Father, lecz jeżeli po za choragwią leżało ich mieszkanie, smucili się. Gdy zaś o przyczynę ich smutku pytałem, odpowiadali jednogłośnie: the English-man is not our friend ${ }^{134}$ ".

Ojciec Pfanner jako przeor osobiście kształtował całą działalność misyjną klasztoru trapistów w Mariannhill. Już w listopadzie 1881 roku przedstawił swój 'program pracy misyjnej' ${ }^{135}$. „Trapiści zostali tutaj powołani, by czarne rasy ludzi doprowadzić do kultury i cywilizacji. Chcą przynieść nie tylko kulturę, ale także chrześcijaństwo. Pragną tubylców przyodziać, by zakryć ich nagość. Przez chrzest przyodziać łaską Bożą, by upiększyć ich dusze. Aby to było możliwe, należy najpierw tych kolorowych uczynić ludźmi. Afrykańczyk musi nauczyć się rozumieć, jaką użyteczność i wartość ma dla niego ziemia, na której żyje. Aby nauczył się jak ją uprawiać, by ona przynosiła owoce. Musi on tę ziemię z miłością pokonać, jeśli chce na niej budować solidne domy i porzucić włóczęgostwo. Musi nauczyć się rzemiosła i przemysłu, jeśli chce zostać spokojnym obywatelem i przyjacielskim ziomkiem. Powinien te dobrodziejstwa cywilizacji i chrześcijaństwa ująć w ręce. Jeśli tego nie przyjmie, albo jeśli zostanie tylko ochrzczony, to znowu zrzuci ubrania i powróci do dzikiego życia w lasach"136. Misjonarze z taką wizją swojej pracy misyjnej potrzebowali trochę czasu aby dostatecznie poznać kraj i jego mieszkańców oraz ich zwyczaje. Pierwszą rzeczą dla każdego misjonarza jest nauka miejscowych języków. Świadczy o tym chociażby wspo-

\footnotetext{
${ }^{131}$ OO. Trapiści w Natalu, dz. cyt., s. 244.

${ }^{132}$ Mariannhill jego powstanie i działalność, „Polski Kalendarz Misyjny” (1939), s. 17.

${ }^{133}$ Por. J. Kępiński, dz. cyt., s. 223.

${ }^{134}$ OO. Trapiści w Natalu, dz. cyt., s. 243.

${ }^{135}$ Cytat za: T. Telega, dz. cyt., s. 49, przypis 3.

136 Tamże, s. 50, przypis 4.
} 
mnienie jednego z misjonarzy, który na jednej drodze misyjnej musiał wysłuchać spowiedzi w 4 językach. „Było to dla mnie wskazówką by nie zaniedbywać nauki języków. (...) Biedny ten misjonarz, który musi się rozbijać z tłumaczem. Każdy, kto czuje powołanie na misjonarza, czy jeszcze jest studentem, czy kapłanem, niech się modli do Ducha św. o dar języków, ale i sam niech się pilnie do ich nauki przykłada"137.

W kilka tygodni po przybyciu misjonarze wybudowali pierwszą kaplicę dla Kafrów ,aby mogli widzieć ceremonie i słuchać śpiewu kościelnego"138. Kafryjskie kobiety również miały wstęp do kaplicy, ale oddzielone były kratą. Po nabożeństwie trapiści zapraszali wszystkich do specjalnie na ten cel wybudowanej szopy, gdzie thumaczyli im przez porównanie przyczynę przybycia trapistów do Natalu a Jezusa Chrystusa do Betlejem. Okoliczność ta, że także kobiety mogły przyjść do klasztoru, wejść do kościoła i słuchać kazań odbierały jako nadzwyczajną łaskę. Przecież to one miały największy wpływ na nawrócenie swoich rodzin. Po nabożeństwie nie zatrzymywały się obok klasztoru, ale natychmiast powracały do domu. Proszono je również, aby do kaplicy ubierały się przyzwoicie $^{139}$.

W celu ukazania piękna liturgii trapiści często sprawowali bardzo uroczyste Msze Święte. Dla wyjaśnienia swej postawy i „spektakularnych widowisk” prowadzili katechezy, podczas których nauczali i wyjaśniali katolickie prawdy wiary. Jednak nie wszyscy jednakowo zapatrywali się na głoszoną im religię. W takiej sytuacji zadaniem misjonarza było poznanie sposobu myślenia miejscowych ludzi, oraz przedstawienie im takich dowodów i porównań, które miały przybliżyć im prezentowane prawdy. Opat Franciszek Pfanner podawał następujący sposób argumentowania: „Na dowód, że nie jesteśmy najemnikami ani oszustami, głosząc Dobrą Nowinę przedstawiłem im, ile dobrego dla nich zrobiłem przez budowę zakładów i rękodzielni dla ich dzieci. Oszust tak nie postępuje. On pragnie zysku nie straty, a my łożymy rocznie wiele tysięcy na wychowanie dzieci kafryjskich, od których żadnej innej nie żądamy nagrody, prócz tej, abyśmy ich widzieli szczęśliwymi i pracowitymi chrześcijanami"140. Na naukę katechizmu i modlitwy przychodziło w niedzielę i w tygodniu - nawet dwa razy dziennie od dwudziestu do pięćdziesięciu osób. W każdą niedzielę ojcowie głosili im kazania, a dwaj bracia zakonni katechizowali ich w języku kafryjskim ${ }^{141}$.

Od samego początku misjonarzom z misji mariannhillskiej nie chodziło o to, aby zapełnić metrykalną księgę, ale przede wszystkim zależało im na tym, żeby wychować miejscową ludność na dobrych chrześcijan. Dzięki temu praca misyjna

\footnotetext{
${ }^{137}$ Przygody misyjne wśród Bazutów, dz. cyt., s. 74.

${ }^{138}$ M. Czermiński, dz. cyt., s. 126.

${ }^{139}$ Por. M. Czermiński, dz. cyt., s. 126-127.

${ }^{140}$ M. Czermiński, dz. cyt., s. 138 i 142.

${ }^{141}$ Tamże, s. 144.
} 
na korzyść katolicyzmu szybko postępowała na przód a misjonarze zabiegali o to, aby jak najwięcej stacji misyjnych wybudować na przydzielonym sobie obszarze. Z „Listu św. Józefa” dowiadujemy się, że do roku 1888 trapiści zdążyli już założyć osiem stacji misyjnych: Reichenau, Einsiedeln, Mariathal, Ötting, Keselar, Loreto, Lourdes i Rankweil. Ostatnią - dziewiąta - przy dużym udziale polskich misjonarzy, nazwali Częstochowa ${ }^{142}$. „Miejscowość ta - czytamy tam - leży na drugim brzegu Umzikulu, obejmuje 770 akrów ziemi, zaopatrzona jest w dobrze zabudowane pomieszczenia i zabudowania gospodarcze, posiada urodzajną ziemię i zajmuje wielmożne (sic) stanowisko w pośród gęsto osiedlonych Kafrów. (...) Posiadamy już wspaniały obraz matki Boskiej Częstochowskiej, przysłany przez jednego z Jej gorliwych czcicieli [z Polski - K.P.]. (...) Aby angielskim urzędnikom na poczcie, na kolei i w porcie ułatwić wymówienie tego ciężkiego imienia, odmienię je cokolwiek w pisowni na Centucow, boby mi wielce złorzeczyli (sic)"143. Zakładanie nowych stacji misyjnych przysparzało niekiedy misjonarzom nie lada kłopotów. Problem polegał na tym, że bardzo trudno było katolickim misjonarzom uzyskać miejsce na założenie takiej stacji. Protestanci, którzy byli jeszcze przed ich przybyciem oraz nowo powstałe sekty ${ }^{144}$ robili wszystko, aby nie dopuścić do osie-

${ }^{142} \mathrm{~W}$ formie Centucow jest obecna na współczesnych mapach. Por. S. Gołąbek, Polskie nazwy w Afryce, ,Kontynenty” (1968) nr 5, s. 40; por. tenże, Wychodźstwo Polskie do Afryki, dz. cyt., s. 8; Zwiqzki Polski i Polaków z Afrykq do roku 1945, dz. cyt., s. 46; por. także, A. Żukowski, Polacy w kraju Springboka do r. 1910, dz. cyt., s. 120; por. tenże, Polonia w Afryce Poludniowej, dz. cyt., s. 183; W kraju złota i diamentów, dz. cyt., s. 99; Udział Polaków w założeniu Misji Mariannhillskiej w Natalu, w Afryce Poludniowej, dz. cyt., s. 410; Polacy w Afryce Poludniowej, dz. cyt., s. 38; por. także, A. Halemba, Polscy misjonarze w Afryce wczoraj i dziś, dz. cyt., s. 38; por. także, J. Knopek, Afryka Poludniowa, duszpasterstwo, dz. cyt., s. 37; por. także, J. Jaworski, W kraju Springboka, dz. cyt., s. 217; por. także, J. Kępiński, dz. cyt., s. 223; por. także, M. Czermiński, dz. cyt., s. 99; por. także, J. Krzyszkowski, S. Hankiewicz, dz. cyt., s. 7.

${ }^{143}$ M. Czermiński, dz. cyt., s. 100.

${ }^{144}$ Przykłady kilku takich sekt działających w południowej Afryce: 1. W obrębie stacji misyjnej Pocieszenie Maryi istniała sekta zwana ,apostoli” czyli uzdrawiający modlitwami. Była to sekta marzycieli, której członkom zdawało się, że posiadają moc cudotwórczą Apostołów. W pewnym kraalu zachorowało troje dzieci w jednej rodzinie. „Apostoli” chcieli uzdrowić je modlitwami. W ostatniej chwili przyszła ciotka-katoliczka, której udało się szybko zabrać dwoje dzieci. Rzecz dziwna, że to właśnie ta dwójka wyzdrowiała, a dziecko pozostawione uzdrawiaczom w bardzo krótkim czasie zmarło. 2. W tej samej okolicy istniały także dwa samodzielne „Kościoły”. Dwóch katechetów protestanckich posprzeczało się między sobą i usamodzielnili się. Każde z wyznań miało swoich wiernych, swoją głowę nieomylną i w odległości 15 minut od siebie po jednej chatce szkolnej jako pierwszym domu bożym. 3. W innym miejscu czarny katecheta zaczął podburzać ziomków przeciwko wysokiemu podatkowi kościelnemu mówiąc im: „To, co umie pastor, umiem ja także. On nawet nie zna naszego języka a ja musiałem wam zawsze kazać i czytać Pismo. Przyjdźcie do mnie, dam wam Wieczerzę Pańską za połowę podatku!” Tak powstał „Kościół Chrześcijański Afryki”. 4. W pobliżu Port Shepstone żył założyciel religii, któremu zwolennicy oddawali boską cześć. Wolno im było zbliżać się do niego tylko na kolanach, a gdy udawał się dokądkolwiek musieli oni kroczyć przed nim w procesji, śpiewając psalmy. Bardzo łatwo zjednał sobie słuchaczy. Posunął się nawet do przepowiedni, że wkrótce wstąpi do nieba. Rzesza wiernych 
dlenia się misjonarzy ${ }^{145}$. Brat Klaudiusz Kowalewski tak oto opisywał całą sytuację: „Idą im na rękę, zresztą w najlepszej wierze i urzędnicy państwowi, należący do takiego czy innego „Kościoła” protestanckiego lub też do której z nowych sekt. Wpływają na naczelnika danego okręgu i wciągają go do swego wyznania. Skoro zaś taki naczelnik należał do jakiegoś „Kościoła” protestanckiego lub sekciarskiego, zamykał przystęp i drogę w swoim okręgu katolickiemu misjonarzowi, nie pozwalając na (...) wybudowanie kaplicy. A do cofnięcia jego zakazu, według istniejących praw, ani rząd nie może go zmusić"146. Mimo tych trudności misja rozwijała się nadzwyczaj pomyślnie. Nowi chrześcijanie bardzo pilnie przychodzili do kościoła i przystępowali do sakramentów świętych. Również wielu pogan i protestantów przychodziło na nabożeństwa. Na niektórych stacjach misyjnych pierwotnie zbudowane kaplice okazywały się zbyt małe i często nawet połowy wiernych nie mogły pomieścić, dlatego też misjonarze zmuszeni byli do znacznego ich powiększania lub wybudowania całkiem nowych i większych. Poświęcenie nowego kościoła odbywało się bardzo uroczyście ,ściśle według rytuału rzymskiego. Na początku pokropiono kościół zewnątrz wodą święconą, potem wewnątrz. (...) Po sumie była mała przerwa, a po niej sakramentalne błogosławieństwo, w czasie którego zabrzmiało Te Deum, które cały kościół z towarzyszeniem orkiestry odśpiewywał po kafersku"147. Ojciec Maurus Kalus pisał w jednym ze swoich listów: „Chwała Bogu więc, dzieło misyjne postępuje naprzód, dzięki gorliwości ludu

i ciekawych chciała być świadkiem tego. Czarny zbawiciel wspiął się na drzewo, tak ażeby go wszyscy widzieli, wygłosił płomienną przemowę, raz jeszcze pobłogosławił wszystkich, wzniósł ręce nad nimi, a gdy wszyscy trwali w ciszy wyczekującej, zaczął „święty” - strasznie wymyślać! - Temu, że nie mógł jeszcze wzlecieć do nieba, winni byli oczywiście jego wierni. On przecież tyle zadawał sobie trudu z nimi, a oni wciąż jeszcze mają mnóstwo grzechów i wad. 5. Inny „zbawca" ludzkości - Anglik - miał w pobliżu Highflats farmę z której nawrócił na swoją wiarę wszystkich swoich dzierżawców. Często czytał Pismo Święte, zjadał codziennie po pół miseczki polewki kukurydzianej i prawił kazania każdemu, kto zechciał go słuchać. Głosił on, że sam Pan Bóg przyszedł do niego i zlecił mu założenie nowego kościoła. Wyliczył nawet, kiedy nadejdzie Sąd Ostateczny. Co prawda pomylił się przy tym, ale niczemu to nie przeszkadzało. Później wiedział już, że dzień ten nastapi w roku 1960. 6. W Rodezji pewien fałszywy prorok, twierdząc, że już umarł i został pogrzebany, ale po tygodniu Bóg go wskrzesił z martwych, głosił kazania z bezpośredniego zlecenia Bożego. Miał na imię Jan, żywił się też według wzoru swojego patrona tylko szarańczami i dzikim miodem. Wywoływał on ogromne poruszenie. Wokół niego gromadzili się nie tylko innowiercy ale i katolicy, gdyż przybrał sobie dwóch uczniów, którzy jeszcze gorliwiej głosili kazania niż on. OO. Jezuici (przeważnie polscy) jako misjonarze tej okolicy, będąc w nie lada kłopocie wezwali na pomoc policję. Ta ujęła go w postępowaniu skróconym i osadziła w więzieniu. „Kościół” jego rozwiał się na cztery wiatry. Por. Zabawne „dzieje Kościoła” z Afryki południowej, „Wiadomości Misyjne” (1935), s. 114.

${ }^{145}$ Por. K. Kowalewski, Po świętach Bożego Narodzenia w Poludniowej Afryce, „Misje Katolickie" (1936), s. 74-75.

${ }^{146}$ Tamże, s. 75.

${ }^{147}$ Poświęcenie nowego kościoła i ćwierćwiecze założenia stacyi (sic!) misyjnej w Częstochowie, „Wiadomości Misyjne” (1914), s. 83. 
mimo trudnych stosunków, jak np., wielka odległość pobocznych stacji ${ }^{148} .(\ldots)$ Garnęli się ludzie na nabożeństwa misyjne $\mathrm{z}$ wielką żarliwością i wytrwałością. Widzieć taką gorliwość czarnych chrześcijan, to oczywiście wielka pociecha dla serca misjonarza" ${ }^{49}$. Mimo znacznych odległości od misji liczba ludności, jaka brała w nich udział przechodziła najśmielsze oczekiwania misjonarzy. Na większości stacji misyjnych misjonarze regularnie odprawiali Msze Św., odprawiali nabożeństwa a z okazji pierwszych piątków, poświęconych Sercu Pana Jezusa, słuchali do stu spowiedzi i udzielali komunii św., także i tym którzy gdzie indziej się wyspowiadali ${ }^{150}$.

Ogromne poświęcenie i praca misjonarzy przyczyniła się do szybkiego rozwoju katolickiej misji. Dla głębszego poznania wiary i jej utwierdzenia misjonarze przeszczepili na grunt afrykański m.in. różnego rodzaju bractwa jakie istniały w ich rodzinnych parafiach w Europie. Na terenie całej misji mariannhillskiej w 1933 roku istniały: 24 Bractwa Serca Jezusowego, po jednym Bractwie Najświętszego Sakramentu, Nauki Religii, Szkaplerznym i Trójcy Przenajświętszej oraz 15 Dzieci Maryi. Ponadto działały: dwa Apostolstwa Modlitwy, Towarzystwo św. Anny i III zakon św. Franciszka ${ }^{151}$. Oprócz tego co roku na kilku stacjach przez trzy do pięciu dni misjonarze wygłaszali kazania misyjne. Miały one wzywać „czarnych chrześcijan do obudzenia w sobie tak ważnych przedmiotów, jak znikomość i marność wszelkiej ziemskiej wielkości i rozkoszy, a z drugiej strony rozważania niezmiernej wielkości i ważności wszystkiego, co jest w związku z wiecznością i wiecznym przeznaczeniem człowieka, wieczną zgubą lub wiecznym zbawieniem" 152 . Ojciec Kalus podsumowując organizację takich misji napisał: „Praca w tych misjach, zapewne nie co uciążliwa, ale i pełna pociechy, wszak to praca dla zbawienia dusz"153.

Na owoce takich misji nie trzeba było długo czekać. Były one jasno widoczne w zaangażowaniu nowo ochrzczonych w pracę na rzecz misji oraz ich pełnym uczestnictwie w katolickich świętach. Jednym z nich było Boże Narodzenie. Brat Klaudiusz Kowalewski w jednym ze swoich listów napisał: „Na żadne inne święta i uroczystości kościelne nie cieszy się nasz czarny ludek i nie oczekuje ich z takim upragnieniem, jak świąt Bożego Narodzenia. Uroczystość przyjścia na świat Bożej Dzieciny ma w sobie coś tak powabnego, że wprost porywa ku sobie tubylców. Cieszą się już długo naprzód na te święta dzieci, młodzież i starcy, a nawet i poganie" 154 . Nie wyobrażając sobie nie przystąpienia $w$ tak wielkie

\footnotetext{
${ }^{148}$ M. Kalus, Rychnow, niedziela przewodnia 1930 roku, „Wiadomości Misyjne” (1930), s. 51.

149 Tenże, Misje w kraju misyjnym, dz. cyt., s. 2.

${ }^{150}$ Por. Mariannhill do roku 1920, „Wiadomości Misyjne” (1921), s. 66.

${ }^{151}$ Por. Stan misji naszej w Afryce r. 1930-go, „Polski Kalendarz Misyjny” (1933), s. 80.

${ }^{152}$ M. Kalus, Misje w kraju misyjnym, dz. cyt., s. 1.

153 Tamże.

${ }^{154}$ Por. K. Kowalewski, Po świętach Bożego Narodzenia w Poludniowej Afryce, dz. cyt., s. 74.
} 
święto do sakramentów już od południa w dzień wigilijny, aż do południa w samo święto przystępowali do spowiedzi świętej. Nawet niechrześcijanie całymi gromadami brali udział we wszystkich nabożeństwach w kościele ${ }^{155}$. Należało podziwiać wytrwałość tych ludzi, znając odległości jakie musieli pokonać do najbliższej im stacji misyjnej, aby mogli wziąć udział w uroczystościach. „Wielu z nich szło przez dwie do czterech godzin afrykańskiej, mozolnej drogi, przynosząc z sobą trochę pożywienia, składającego się zwykle z placka kukurydzianego i o tak nędznym pożywieniu byli obecni na Pasterce o północy, z rana zaś wszyscy słuchali drugiej Mszy św. (...) i dopiero po głównym nabożeństwie i po sakramentalnym błogosławieństwie, co zwykle o pierwszej godzinie po południu się kończy, rozchodzili się do swoich domostw"156. Innym świętem uroczyście obchodzonym w misji mariannhillskiej było Boże Ciało. Dla „czarnych chrześcijan uroczystość ta była ściśle z sercem złączona"157. Święto to było obchodzone w następną niedzielę, ale wszelkie przygotowania odbywały się już od piątku. Jeden z ojców w swoim liście do redakcji „Wiadomości Misyjnych” następująco opisał zaangażowanie mieszkańców misji: „Ulice są czyszczone i przyozdabiane, kościół udekorowany, łuki tryumfalne i ołtarze poustawiane itd. Pracę tę dzielą pomiędzy sobą Bracia i Siostry z czarnymi robotnikami i dziećmi szkolnymi. - Ogrody nasze i zakłady leśne dostarczyły nam bujnej zieleni (...) także i kwiatów mieliśmy bardzo wiele, chociaż tutaj u nas Boże Ciało wśród afrykańskiej zimy przypada"158. O samej zaś uroczystości Bożego Ciała pisał: „Po Mszy św. wyruszyła wspaniała procesja z kościoła. Na czele postępowały dzieci szkolne z krzyżem i choragwiami, po za nimi siostry misyjne od Najświętszej Krwi, biali i czarni śpiewacy, dziewczęta rzucające kwiatki, kler i księża zakonni z Przewielebnym O. Opatem, który w licznej asystencji niósł Najświętszy Sakrament w końcu Bracia i tysiące czarnego i białego ludu. Przy czterech ołtarzach śpiewał chór klasztorny a podczas pochodu dzieci i wychowawcy z różnych szkół i zakładów śpiewały pieśni o Najświętszym Sakramencie. Cała ta uroczystość odbywała się w bardzo budujący sposób. Po procesji pozostał Najświętszy Sakrament wystawiony aż do wieczora. Godzinę za godzinę tłoczył się lud w około wielkiego ołtarza i pewnie jeszcze nigdy, jak tylko klasztor w Mariannhill istnieje, nie wznosiły się tak szczere i gorące modły do „Eucharystycznego Księcia”. Niechaj owoc tych modłów będzie trwałym i prawdziwym błogosławieństwem Bożym"159.

Założyciel misji mariannhillskiej wychodził $\mathrm{z}$ następującego założenia: „gdzie Kościół katolicki się zakorzeni, tam jest już nie do usunięcia”. Z tego też

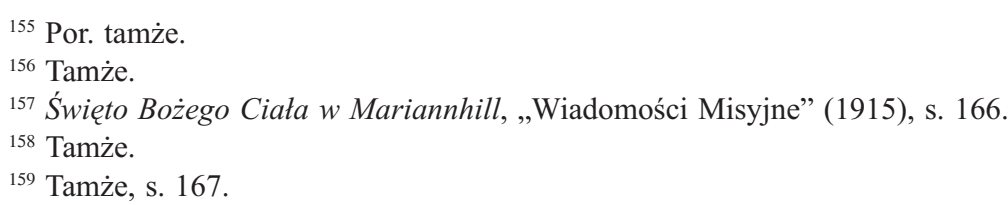


powodu kupował ziemie na których zakładał stacje misyjne. Było to myślenie skierowane ku przyszłości Kościoła katolickiego w południowej Afryce ${ }^{160}$.

\section{Zaangażowanie w szkolnictwie}

Szkoły były niekiedy, przed kościołem czy domem dla misjonarzy, pierwszymi budynkami jakie powstawały na terenie stacji misyjnej ${ }^{161}$. Pionierkami szkolnictwa w misji mariannhillsjkiej były siostry pochodzące z Polski. Jedną z założycielek i organizatorek szkół była wspomniana już siostra Maria Lassak ${ }^{162}$. Do budowy szkoły skłaniała misjonarzy przede wszystkim ,większa chwała Boża oraz doczesne i wieczne dobro dziatek, którym przez szkołę dajemy wszystko co najlepsze, na co nas stać, naukę i religijne wychowanie" ${ }^{163}$. Zdawali oni sobie sprawę jak ważna jest szkoła w procesie wychowywania i kształtowania dzieci i młodzieży. W tym względzie także nie obyło się bez początkowych problemów. Pierwszą trudnością z jaką musieli się zmierzyć misjonarze było nakłonienie tubylców do posłania swoich dzieci do szkoły. Kolejnym problemem była bariera językowa. Misjonarze posługiwali się głównie językiem niemieckim, tylko jeden z nich znał język angielski, poza tym nie było wśród nich nikogo kto znałby język kaferski, z tego też względu musieli poszukać miejscowych nauczycieli. Wreszcie potrzebne były odpowiednie pomieszczenia $^{164}$. Opat Franciszek opisał w swoich listach $-\mathrm{z}$ wielką prostotą i humorem owe trudności, jakie musiał pokonać w pierwszych latach spędzonych w Natalu: „W pierwszych tygodniach pobytu naszego w Natalu wybudowaliśmy dom mieszkalny w nadziei, że z braku Kafrów zgłoszą się do szkoły dzieci białych. Jakoż wkrótce zgłosiło się dwóch chłopców, z których jeden, ponieważ wychowywał się długo między kafryjskimi dziećmi bardzo był zaniedbany pod każdym względem. Rozpoczęliśmy więc naukę z tymi chłopcami. Poza godzinami nauki uczęszczali do warsztatu, aby nauczyć się rzemiosła; jeden próbował szewstwa, drugi sztuki drukarskiej. Zaledwie kilka dni byli w szkole, a wieść rozeszła się między sąsiadami; dwie włoskie rodziny przysłały swoje dzieci do szkoły i warsztatów. Tych pierwszych uczniów i wielu następnych, przyprowadzili do nas katoliccy misjonarze. Wiedzieli oni dobrze, że nie było dla sierot lepszego, pewniejszego i tańszego miejsca jak Mariannhill. Cóż bowiem więcej potrzeba takiemu chłopakowi, jeżeli ma nauczyciela, majstra, ubranie i pożywienie. To wszystko u nas dostają"165.

${ }^{160}$ Por. za: T. Telega, dz. cyt., s. 68, przypis 38.

${ }^{161}$ Por. J. Różański, Misje a promocja ludzka wedtug dokumentów soborowych i posoborowych oraz praktyki misyjnej Kościoła, Warszawa 2001, s. 145; por. tenże, Inkulturacja Kościoła wśród ludów Środkowego Sudanu, Poznań 2004, s. 286-287.

${ }^{162}$ Por. A. Żukowski, Kobiety Polskie w Afryce - przyczynek do monografii problemu, dz. cyt., s. 367; por. tenże, $W$ kraju złota i diamentów, dz. cyt., s. 98.

${ }^{163}$ Dzienna szkoła dla dzieci Kulisów, „Wiadomości Misyjne” (1914), s. 28.

${ }^{164}$ Por. M. Czermiński, dz. cyt., s. 124.

${ }^{165}$ OO. Trapiści w Natalu, dz. cyt., s. 308. 
W 1884 r. założyciel misji mariannhillskiej wprowadził do szkół swój program nauczania. Podzielił on wychowanków na trzy klasy, w których starsi uczniowie dwie i pół godziny spędzali w szkole, a od ósmej do jedenastej oraz od czternastej do szesnastej w różnego typu warsztatach. Otrzymywali oni darmowe lekcje, wyżywienie, łóżko i mieszkanie. W krótkim czasie, młodzieńcy w wieku od 15 do 18 lat, sami zaczęli się zgłaszać jako kandydaci na murarzy, stolarzy, cieśli czy kowali. Trapistom pomagał też młody człowiek z Basutolandu, który już jako dziecko przyjął wiarę katolicką i mówił po angielsku. Odwiedzał on Kafrów w ich osadach i uczył braci zakonnych języka kafryjskiego ${ }^{166}$. Porządek dzienny w szkole przedstawiał się następująco: „O godz. 6 rano zimą i latem, wstają i mówią pacierz. O $1 / 26$ jest Msza, potem przez $1 / 2$ godziny nauka religii w kościele. Od godz. 7-8 jest robota ręczna, w ogrodzie i w domu, w myśl słów Ora et labora. Od godz. 8-12 nauka szkolna, o godz. 10 jest pół godziny przerwa. Popołudniu roboty. Chłopcy i parobcy pracują z Braćmi na polu, dziewczęta pod doglądem Sióstr - w ogrodzie i w domu. Tak cały dzień dobrze się spożytkowuje, przy czym mamy sposobność, nie tylko uczyć dzieci potrzebnych wiadomości, ale - co jeszcze więcej znaczy - zaprawiać jej do pracowitości, porządku i innych cnót naturalnych"167. Mariannhillski system szkolony obejmował klasy elementarne, średnie oraz klasy normalne seminarium nauczycielskiego. Ten podział odpowiadał planowi rządu, do którego misjonarze musieli się dostosować. Klasy elementarne obejmowały 6 lat, klasy średnie 2 a normalne 3 lata. Do piątego roku nauki misja wychowywała uczniów bezpłatnie. Ci, którzy chcieli podjąć dalszą naukę, sami musieli za nią płacić. Koszt rocznej nauki wynosił 12 funtów rocznie. Na początku uczono w szkołach tylko czytania i pisania oraz nieco rachunków ale kiedy szkoły dostały się pod nadzór państwowy wtedy wymagano już więcej. W roku 1914 misjonarze założyli pierwsze seminarium nauczycielskie. W tym czasie było to jedyne katolickie seminarium w Natalu. W pierwszym roku miało ono tylko 6 kandydatów lecz liczba ich tak szybko rosła, że pięć lat później było ich już 52. W wyższych klasach nauczano fizjologii, botaniki, algebry i geometrii. Głównym przedmiotem nauki we wszystkich typach szkół była religia ${ }^{168}$.

Wykształcenie młodych tubylców było zróżnicowane. Początkowo uczono ich moralności i pracy ręcznej oraz katechizmu. Dziewczęta zapoznawały się z obowiązkami żony i matki. System ten został wprowadzony po to, aby młodzi Kafrowie docenili naukę świętej wiary. Obawiano się bowiem, - jak to zdarzało się w szkołach protestanckich - że uczniowie, po wyuczeniu się zawodu, znowu powrócą do pogaństwa, ku wielkiemu zgorszeniu chrześcijan ${ }^{169}$. Od 1920 r. mi-

\footnotetext{
${ }^{166}$ Por. tamże, s. 309.

${ }^{167}$ Monte Cassino, „Wiadomości Misyjne” (1914), s. 44.

${ }^{168}$ Por. Nasza szkoła św. Franciszka w Mariannhillu, „Wiadomości Misyjne” (1919), s. 70.

${ }^{169}$ Por. M. Czermiński, dz. cyt., s. 155.
} 
sja mariannhillska rozpoczęła prowadzenie szkoły zimowej dla czarnych nauczycieli. Dziesięciodniowy kurs podczas długich ferii zimowych miał za cel „,przez kolejno po sobie następujące wykłady natury teoretycznej i praktycznej w różnych przedmiotach naukowych dać nauczycielom sposobność do rozszerzenia swych wiadomości i do nabycia lepszego poglądu na różne rzemiosła" ${ }^{170}$. Rząd chciał, aby nauczyciele posiadali nie tylko teoretyczną wiedzę, lecz także, i to przede wszystkim, aby byli pilnymi i praktycznymi pracownikami, pożytecznymi dla ludzi i kraju. Szkoła ta wśród czarnych nauczycieli cieszyła się bardzo dużym powodzeniem. Już w pierwszym roku jej działalności zgłosiło się do niej 350 nauczycieli i nauczycielek. Jednakże tylko 207 można było przyjać, gdyż tylko dla tylu było miejsce. Wykłady w szkole zimowej dotyczyły następujących przedmiotów: zarząd szkolny, podstawy wychowania, metoda nauczania, historia Zulusów, język kaferski, fizjologia i higiena, arytmetyka, geografia, historia powszechna, język angielski i śpiew. Nauczycielki uczyły się gospodarstwa domowego, kucharstwa, pieczenia, pielęgnowania chorych, rannych itp. Na zakończenie tego kursu wszyscy nauczyciele zdawali egzamin pisemny z wysłuchanych wykładów ${ }^{171}$.

W 1935 roku na terenie misji mariannhillskiej działało 175 szkół powszechnych, 12 szkół średnich oraz 3 szkoły ,wyższe” (według naszych standardów trzeba o nich mówić jako o „średnich”). Ponadto istniało 7 szkół rękodzielniczych, 1 rolnicza, 1 dla katechetów i 1 seminarium nauczycielskie. Łącznie nauką było objętych około 4500 chłopców oraz 7000 dziewczą ${ }^{172}$. O efektywności działań misjonarzy mariannhillskich na rzecz szkolnictwa w południowej Afryce świadczy wypowiedź głównego inspektora szkolnego, w czasie jednej z jego wizyt w Mariannhill. Powiedział on wtedy: „Wy studenci możecie rzeczywiście mienić się szczęśliwymi, że dostaliście się do tej szkoły. Jest to doprawdy bardzo dobra szkoła i słyszeliście, że wyniki nauki były znakomite. Dzieci, macie diamenty w swoich rękach, nie igrajcie z nimi i nie odrzucajcie ich precz. Otwierajcie dobrze wasze oczy i uszy, dopóki tutaj jesteście, abyście się nauczyli jak najwięcej. Patrzcie, czego już to mariannhillscy misjonarze dokazali i czego to jeszcze nie czynią. Jakie to pozakładali piękne ogrody, ile to pobudowali domów, jakie oni ładne umieją wyplatać koszyki i wiele innych rzeczy! Patrzcie jak pracuja, jacy oni pilni! Naśladujcie ich przykład! Przyswajajcie sobie wszystko dobrze, abyście zdolni byli kiedyś tego samego uczyć swoje dzieci. Mariannhill to doprawdy cudowna miejscowość!"173

${ }^{170}$ Szkoła zimowa dla czarnych nauczycieli w Mariannhillu, „Wiadomości Misyjne” (1920), s. 49.

${ }^{171}$ Por. tamże.

${ }^{172}$ Por. Nowiny kościelne i świeckie, „Wiadomości misyjne” (1935), s. 91.

${ }^{173}$ Nasza szkoła św. Franciszka w Mariannhillu, dz. cyt., s. 71. 


\section{Działalność wydawnicza}

Istotną rolę $\mathrm{w}$ działalności misyjnej odgrywała mariannhillska drukarnia. Choć jej początki były bardzo skromne, to jednak była w stanie zaspokoić bieżące potrzeby misji. Pierwotnie misjonarze drukowali w niej czasopisma, nuty, książki szkolne, dzieła religijne, gramatyczne i encyklopedyczne w różnych językach. Kolebką mariannhillskiej drukarni była prosta buda blaszana, mająca wzdłuż i wszerz po 12 stóp. Od 1883 r. drukowali prostą prasą ręczną przywiezioną do Natalu z Dunbrody. Prasa ta pozwalała odbijać tylko formaty do czterech kartek, na godzinę misjonarze uzyskiwali tą maszyną 200 jednostronnych odbitek. W taki oto sposób misjonarze mariannhillscy wydawali pierwsze polskie czasopismo w Afryce - „List św. Józefa”"174 (a drugi druk polski, który kiedykolwiek przedtem ukazał się na tym kontynencie), które wychodziło od roku 1885! Pismo to misjonarze wysyłali także do Polski. Redaktor Czermiński, który miał w ręce numer z 1 października 1888 roku, tak go opisał: „Na egzemplarzu, który mamy przed sobą, po tytule o ozdobnej winietce stoi napis: Rocznik 4; 1 październik 1888, nr 7; na ósmej stronicy u dolu: Czcionkami drukarni św. Tomasza z Akwinu w Opactwie Trapistów Mariannhill. Tenże numer zawiera następujące artykuliki: Nasze stanowisko względem Najśw. Serca Pana Jezusa, Wielkie przeksztatcenie, Nowy Rankweil, Częstochowa, Postęp kaferskiej kultury"175.

W 1887 r. misjonarze przenieśli „drukarnię” do budynku odległego o pół godziny od Mariannhill, nad rzeką Umhlatuzani. Stosunkowo szybko udało im się sprowadzić bardziej nowoczesne maszyny drukarskie m.in. maszynę rotacyjną. Tej ostatniej misjonarze używali przeważnie do druku mariannhillskiego kalendarza. Kiedy jednak w ciagu 10 lat coraz bardziej uwydatniało się, że przez podwójny transport, mianowicie papieru z Niemiec do Mariannhill, oraz gotowych kalendarzy z powrotem do Niemiec, transport kosztuje więcej, z tego powodu kalendarze zaczęto drukować w Europie. Tym samym maszyna stała się zbyteczna i przy pierwszej sposobności misjonarze sprzedali ją indyjskiej spółce wydawniczej do Durbanu ${ }^{176}$. Z czasopism misjonarze początkowo wydawali „The Natal Record", angielski dwutygodnik, zajmujący się głównie kwestiami religijnymi i misji kaferskiej, jak też bieżącymi zagadnieniami politycznymi i katolickimi. Jednak z braku abonentów pismo to upadło po czterech latach. Dla klasz-

${ }^{174}$ Por. J. Kępiński, dz. cyt., s. 223; por. także, S. Gołąbek, Wychodźstwo Polskie do Afryki, dz. cyt., s. 8; por. tenże, Zwiazki Polski i Polaków z Afryka, dz. cyt., s. 46; por. także, A. Żukowski, Polonia w Afryce Poludniowej, dz. cyt., s. 183; por. tenże, Polacy w kraju Springboka do r. 1910, dz. cyt., s. 120; $W$ kraju złota i diamentów, dz. cyt., s. 99; Udziat Polaków w założeniu misji mariannhillskiej w Natalu, w Afryce Poludniowej, dz. cyt., s. 410; Polacy w Afryce Poludniowej, dz. cyt., s. 38; por. także, J. Knopek, Afryka Poludniowa, duszpasterstwo, dz. cyt., s. 37.

${ }^{175}$ M. Czermiński, dz. cyt., s. 99.

${ }^{176}$ Por. Drukarnia św. Tomasza z Akwinu w Mariannhillu, „Wiadomości Misyjne” (1919), s. 82 . 
toru i samej misji drukowano periodyczne pisemka, takie jak: „Pastror bonus” czy „Familia”. Jako łącznik między misją a liczną rzeszą dobrodziei, którzy wspierali misję mariannhillską od samego założenia misji, wydawali miesięcznik „Niezapominajki”. Ponieważ z upływem czasu abonentów ciagle przybywało, z tych samych powodów, co kalendarz, musieli jego druk przenieść do Niemiec.

Najważniejszą jednak i najgłówniejszą czynnością w mariannhillskiej drukarni był druk licznych dzieł religijnych, książek szkolnych itp., nie tylko na własne potrzeby, lecz także dla misji innych zgromadzeń, jak oblatów, jezuitów czy dominikanów. W 1919 roku z drukarni wychodziły książki w 20 językach: łacińskim, niemieckim, angielskim, francuskim, polskim, chińskim (mała gramatyka), holenderskim (afrykanerskim), Zulusów (kaferskim), Sindebela (Rodezja), Koja (Keilandia), Swazi (narzecze mowy Zulusów, Zwazja), Sesuto (kraj Bazutów), Chimanylka (Rodezja), Chiswina (Rodezja), Chikuni (Rodezja), Chitonga (Rodezja, kraj Tonga), Chinyungwe (portugalska kolonia w dystrykcie Tete), Chizezuro (kraj Maszonów), Seshuane (kraj Beczwanów), Kiszambala (Zach. Usambara). W językach tych drukowano także wielkie i małe katechizmy, historie biblijne, książki do nabożeństwa i śpiewniki, pisma apologetyczne, broszurki religijne, elementarze i wypisy, gramatyki, słowniki, reguły, konstytucje, rytuały, ceremoniały itd. Niektóre z tych książek, jak np. Wielki słownik zulusko-angielski i mniejszy angielsko-zuluski jak też wielka niemiecko-zuluska gramatyka języka zuluskiego nie miały pod względem naukowym i pedagogicznym sobie równych. W tym czasie drukarnia mariannhillska dzierżyła w południowej Afryce wyłączny monopol na druk katolickich dzieł w językach lokalnych ${ }^{177}$.

\section{Udział w rozwoju gospodarczo-społecznym}

Misjonarze mariannhillscy mieli także udział w rozwoju gospodarczo-społecznym miejscowej ludności. Szczególne zasługi na tym polu miał o. Bernard Huss. Był on pierwszym i jedynym w tym czasie misjonarzem, który skutecznie zorganizował katolickich nauczycieli, założył stowarzyszenie rolnicze i banki ludowe oraz rozpowszechnił kredyty rolnicze wśród czarnych w całej południowej Afryce ${ }^{178}$.

Wiele starań włożyli misjonarze aby rozpropagować wśród tubylców tzw. apostolat pracy na roli. Starali się przekonywać miejscowych, że praca na roli uczy uczciwości i moralnego życia ${ }^{179}$. O tym jak bardzo krajowcy przekonali się

\footnotetext{
177 Por. tamże, s. 82; por. także, OO. Trapiści w Natalu, dz. cyt., s. 244.

${ }^{178}$ Por. Szósty zjazd gospodarczo-społeczny na stacji misyjnej Lourdes Wikariatu Apostolskiego Mariannhill, „Wiadomości Misyjne” (1928), s. 49-50.

${ }^{179}$ Por. A. Żukowski, W kraju złota i diamentów, dz. cyt., s. 99.
} 
do pracy w rolnictwie świadczył choćby fakt organizowanych co roku wystaw rolniczych chłopskiej ludności tubylczej. Każda taka wystawa gromadziła ok. 100 do 200 wystawców a liczba eksponatów wahała się nawet w okolicach $700^{180}$. Lokalny dziennik „Natal Witness” o jednej z takich wystaw, które odbywały się w Mariannhill napisał m.in. „Pokazy na wystawie wykazują jakość najlepszą. Każdy wystawiony przedmiot wzbudzał ciekawość i podziw. Już sama odzież najróżnorodniejsza, szyta ręką lub maszyna, zasługuje, by oglądały ją także szersze koła. Każda cząstka odzieży żeńskiej, dziecięcej czy męskiej wykazywały robotę najstaranniejszą. Wzorce wyrobów cukrowych i pasztecików, kakao i inne słodycze wywierały wrażenie bardzo dobre a wystawiano je najponętniej. Płody ogrodu podziwiali szczególnie owi zwiedzający, którzy skutkiem suszy nie zdołali sami nic wyhodować w ogrodzie. Wystawcy pokazali cały dział rozmaitych warzyw, które wyhodowali w tej porze suchej, były tam: kalafiory, kapusta, buraki, fasola, cebula, pomidory, wszystkie owoce nie naganne z ogrodu klasztornego. Rzemieślnicy (rękodzielnicy): budowlańcy, kołodzieje, kowale itd. mieli na pokaz znakomite wzorce i rysunki z zakresu swoich rzemiosł. Stołki sporządzone $z$ trawy (łyka) osiagały w sprzedaży ceny najwyższe; coraz więcej zdumiewał się człek, jak też to tubylcy zdołali nauczyć się wyrobu takich rzeczy"181. Widząc tak wielkie zainteresowanie autochtonów pracą na roli, misjonarze mariannhillscy mogli być dumni, że ich trudy i zabiegi nie pozostały bezskuteczne, ale wywołały wśród krajowców zamiłowanie do pracy.

Dzięki wielkiemu autorytetowi jakim cieszyli się misjonarze wśród tubylców mieli oni także duży wpływ na zmianę ich dotychczasowego stylu życia. Świadczy o tym choćby fakt, że udało im się przekonać miejscową ludność do zwyczaju używania odzieży. Wiele wysiłku włożyli misjonarze aby przekonać miejscową ludność do tego zwyczaju. Nie było to łatwe, gdyż w ciepłym klimacie nie czuli oni potrzeby ubierania się. Ponadto ,zarzucali oni temu zwyczajowi, że jest to ciężar dotąd nie znany, przysparza roboty i kosztuje pieniądze" ${ }^{182}$. Mimo wielu upomnień, przykrości i zmartwień jednemu z braci udało się przerobić lud kaferski nad rzeką Umhlatuzane i pokazał im - naocznie - jak wdziewa się spodnie. Wielkim postępem w kwestii ubraniowej było wprowadzenie do niższych klas w szkole nauki szycia dla chłopców. Jeden z braci uczył ich przyszywać guziki, łatać spodnie i marynarkę, uszyć zapaskę, obrobić chusteczkę do nosa, w tym celu, aby później chłopak sam umiał sobie przywieść swoje ubranie do porządku. Brat Oton w jednym ze swoich listów całą „historię” opisał następująco: „Kafer sprawiwszy sobie nowe ubranie, chodził w nim tak długo, dopóki

${ }^{180}$ Por. Afryka Poludniowa. - Natal - Mariannhill. - Wystawa rolnicza Afryki Poludniowej, „Misje Katolickie” (1933), s. 378.

${ }^{181}$ Mariannhill jego powstanie i działalność, dz. cyt., s. 22.

${ }^{182}$ Listy z poludniowej Afryki, „Wiadomości Misyjne” (1920), s. 57.

${ }^{183}$ Tamże, s. 58. 
się nie podarło; potem nie miał mu go kto naprawić, więc chodził obdarty, aż zebrał środki na kupno nowego ubrania. (...) Brat misyjny, zadający sobie trud nauczenia chłopców kaferskich szycia, ma większą zasługę wobec cywilizacji, niż gdyby szył same nowe i modne ubrania"183. Szycia uczyły się także dziewczyny. Owocem tych zmian było znaczne rozpowszechnienie się maszyn do szycia. W całej okolicy Mariannhill stało się zwyczajem, że chrześcijańska dziewczyna sprawiała sobie skrzynię, a gdy wychodziła za mąż nabywała maszynę do szycia. W obwodzie Mariannhill było 150 maszyn do szycia i trzy szwaczki. Na zakończenie swojego listu wspomniany już brat napisał: „Rozpowszechnienie maszyn do szycia świadczyło o tym, że uczymy ludzi nie tylko modlić się, lecz także zaprawiamy ich do pracy"184.

\section{Wkład w rozwój opieki zdrowotnej}

Stałym elementem działalności misyjnej misjonarzy była również troska o chorych. Przy zakładaniu stacji misyjnej zawsze pamiętali aby także dla chorych, choćby początkowo upatrzyć skromne miejsce. Oprócz tego przygotowywali tzw. ambulatorium w którym pacjenci otrzymywali doraźną pomoc. Dzięki temu można im było m.in. opatrzyć wszelkiego rodzaju rany czy też dać potrzebne lekarstwa. Szpital z prawdziwego zdarzenia powstał w Mariannhill w 1927 r. „Łatwo pojąć jak się czarni cieszą, a nawet dumni są, że tak się o nich dba”"185. Misjonarze nie tylko pamiętali o chorych w szpitalu, ale i o tych, których z braku miejsca do szpitala przyjąć nie mogli. W przypadku kiedy nie było możliwe przywiezienie chorego do szpitala lub źle znosił podróże brat lub siostra wyjeżdżali z pomocą do potrzebującego. Poza leczeniem misjonarze zajmowali się również uświadamianiem miejscowej ludności jak ważna dla zdrowia jest higiena oraz jak zachowywać zdrowy tryb życia. W tym celu wędrowny brat - lekarz robił wykłady o niesieniu pomocy w nagłych wypadkach i o pielęgnowaniu dzieci. Zwracał on uwagę, aby przestrzegali schludności, pamiętali o świeżym powietrzu, zdrowym mieszkaniu i by nie wierzyli znachorom, dla których jedynym celem był tylko ich wyzysk ${ }^{186}$.

Wybuch I wojny światowej w 1914 roku spowodował poważne ograniczenia w pracy misjonarzy. Mimo rozporządzenia i obietnic ze strony rządu, że nie ma on zamiaru internować misjonarzy, wielu z nich zostało uwięzionych a pozostali mieli duże ograniczenia w komunikacji. Jednym z internowanych Polaków był o. Maurus Kalus. Ojcowie i bracia posiadający obywatelstwo niemieckie nie

\footnotetext{
${ }^{184}$ Tamże.

185 Opieka dla chorych w misji mariannhillskiej, „Polski Kalendarz Misyjny” (1929), s. 19.

${ }^{186}$ Por. tamże; por. także, Opieka nad chorymi w misji mariannhillskiej, „Wiadomości Misyjne" (1928), s. 94.
} 
mogli opuszczać stacji misyjnej bez pisemnego pozwolenia komisarza w Pretorii. Nawet idąc na wezwanie do chorego musieli mieć zgodę na opuszczenie stacji. Po czasie przepis ten został nieco złagodzony, tak, że misjonarze mogli odwiedzać boczne stacje mariannhillskie ale tylko w celach duszpasterskich. Nazywało się to „odwiedzeniem chorych"187. Pomimo tych i innych bolączek wojennych i różnych jeszcze powojennych działalność Mariannhill wzmogła się tak dalece, że w 1922 r. obszar misyjny mariannhillski skupiony w Natalu Stolica Apostolska podniosła do godności wikariatu apostolskiego, rozszerzając go poza dotychczasowe granice ${ }^{188}$.

Dzięki pracy misjonarzy oraz zaangażowaniu w nią miejscowej ludności misja mariannhillska stała się celem wielu zwiedzających. Jednym z nich był sam książę Jerzy z Anglii. Pewien znany pisarz, zwiedziwszy Mariannhill tak oto wyraził się o nim w swoim sprawozdaniu: ,Jako hymn pochwalny dla modlitwy i pracy leży Mariannhill między pagórkami palmowymi Natalu" ${ }^{189}$. Pełne zachwytu są także słowa jednego z misjonarzy, który przybył do Mariannhill z kraju Beczuana. „Obchodząc okolicę doszedłem na wyżynę, skąd miałem znakomity widok na Mariannhill i jego otoczenie najbliższe. Jak daleko okiem sięgnąć, wszystko pokryte było świeżą zielenią. Od wschodu powitały mnie wysokie wieże kościołów, pracownie, szkoły, szpitale, zakłady, klasztor i konwent. Wszystko otoczone było ogrodami warzywnymi i sadami owocowymi. Mariannhill, miasto w miniaturze! Nieomal jak w bajce wyglądały z zielonej oprawy rozmaite budynki wystawione z cegły czerwonej. Nie sterczą one tam w jakiejś nużącej jednostajności, lecz z powabną odmianą, nierówne kształtem i wielkością, rozchełstanymi, bujającymi liniami rozsiadając się po łagodnie falistej powierzchni krajobrazu. Własną uwydatniając swoistość kładą się pomiędzy ogrody zielone i pod palmy cieniste. Jakoby stróża wiernego pomiędzy tym 'w górę - na dół' wielu tych budynków, za zielenią lasów i przepyszną grą kras kwiatów dostrzega się osobliwą, stromą Górę Stołową ${ }^{190}$ jedyny cień w całej tej scenerii"'191.

Powstanie i rozwój misji mariannhillskiej wpisuje się w nurt odnowy misyjnej przełomu XIX i XX w. Wiele poszczególnych wydarzeń i okoliczności, choć oczywiście z cechami charakterystycznymi dla tej misji, występowało analogicznie na innych misjach tego okresu.

\footnotetext{
${ }^{187}$ Por. Misja Mariannhillska w czasie wojny światowej, dz. cyt., s. 1-3, 9.

${ }^{188}$ Por. Mariannhill jego powstanie i działalność, dz. cyt., s. 20.

189 Tamże, s. 22.

${ }^{190}$ Prawdopodobnie autor miał na myśli Góry Smocze. Góra Stołowa (1087 m n.p.m.) znajduje się w okolicach Kapsztadu.

${ }^{191}$ Por. Mariannhill jego powstanie i działalność, dz. cyt., s. 22-23.
} 


\section{SUMMARY}

In 1879 Francis Pfanner settled together with 30 co-brothers on the west coast of Southern Africa on Maria-Anna's Hill (Marianhill). They built the monastery which in the short time became the centre of the Christianity in the entire area Craftsmen workshops and schools started to come into existence. Altogether 265 monks lived in the monastery, many of them from Poland. They started to open new missionary posts, sometimes even up to $200 \mathrm{~km}$ away from Marianhill. In 1909 Pope Pius the $10^{\text {th }}$ created a new missionary congregation - Marianhill Missionaries. Their work is still practically unknown. To the large extend it was co-founded by Poles and often supported by them.

\section{Key words:}

Abbot Francis Pfanner, Marianhill Missionaries, Catholic Mission of $19^{\text {th }}$ century, South Africa

\section{Słowa klucze:}

Opat Franciszek Pfanner, misjonarze z Mariannhill, Misje Katolickie - XIX w., Afryka Południowa 